\title{
COVID-19 in Management Studies: A Systematic Literature Review
}

\author{
Michela Piccarozzi * (D), Cecilia Silvestri (1) and Patrizio Morganti
}

Department of Economics, Engineering, Society and Business Organization, University of "Tuscia" of Viterbo, 01100 Viterbo, Italy; c.silvestri@unitus.it (C.S.); morganti@unitus.it (P.M.)

* Correspondence: piccarozzi@unitus.it

Citation: Piccarozzi, M.; Silvestri, C.;

Morganti, P. COVID-19 in

Management Studies: A Systematic

Literature Review. Sustainability 2021,

13, 3791. https://doi.org/10.3390/

su13073791

Academic Editors:

Isabel-María Garcia-Sanchez,

Filippo Vitolla and Nicola Raimo

Received: 22 February 2021

Accepted: 25 March 2021

Published: 29 March 2021

Publisher's Note: MDPI stays neutral with regard to jurisdictional claims in published maps and institutional affiliations.

\begin{abstract}
In 2020, the whole world had to face a pandemic with inevitable profound changes in all aspects of life, from the social to the economic sphere. The profound economic crisis that followed the rise of the pandemic has pushed firms and researchers to question the necessary changes and new challenges for the survival of businesses. In this scenario, the aim of the paper is to analyze and classify the main contributions published on the topic of COVID-19 in managerial literature, seeking to discover the perspective and the gaps and outline future avenues of research. A systematic review of the literature has been performed. The results highlight the orientation of studies in this field and the various links between different aspects that emerged. Limitations and implications complete the research.
\end{abstract}

Keywords: COVID-19; pandemic; management; managerial; perspective; systematic literature review

\section{Introduction}

In 2020, the whole world had to face with the COVID-19 pandemic with inevitable profound changes in all aspects of life, from the social to the economic sphere. In particular, firms and production have suffered a profound shock, even greater than that suffered during the Great Depression and the Second World War [1], because in relation to the progress of the pandemic, many states have implemented policies such as "social distancing" and "stay-at-home" [2]. These interventions have made it possible to manage the pandemic from a health point of view, limiting the number of victims [3], but at the same time have opened up numerous scenarios of difficulty for businesses: reduction in demand, interruptions and also disruptions in supply chain and numerous other impacts [4]. The difficulties that have emerged and the policies adopted have had a negative impact on numerous sectors [5]. The first and most affected was tourism [6], followed by a global progression on numerous other sectors (i.e., food, sport, and agriculture) $[7,8]$. These profound impacts have also had repercussions on the dynamics of consumption and on the attitude of consumers. In particular, the emotional sphere of consumers was affected [9]. People reacted to restrictions by implementing panic purchasing behaviors [10] and shifting attention to online purchases [11]. In this scenario, technology has taken a crucial role in pushing firms to initiate or complete the digital transition process [12]. From the medical field, education, commerce, and management in general, technological tools have supported in various ways since the early stages of the pandemic [13-15]. From the analysis of this complex context that is taking shape day after day, pandemic has brought significant changes globally and certainly in management, from the definition of new business dynamics and strategies to consumer analysis and marketing [16]. All firms, from micro to small and medium-sized enterprises found themselves facing new challenges, new global scenarios and new market needs [17]. Therefore, COVID-19 has guided researchers from around the world to observe and analyze in depth the various changes and impacts on the firms and management with a proliferation of literature in 
a very short space of time [18]. The numerous researches make it necessary, at the same time, to have an organic and systematized vision to fully understand the implications of this pandemic and to grasp points of contact and synergies in different fields of study. In the managerial fields, few contributions have started a process of systematization of the literature $[15,19]$. However, the speed of development of the pandemic's consequences and of the related studies requires constant investigation and updating of the analysis.

Before starting the research, the existing literature was analyzed to identify any similarities/differences with the present research work. From the literature it was possible to identify two papers that focus on the study of the COVID-19 topic in the managerial field using a schematic and repeatable approach to the literature. The first contribution analyzed [15] is a bibliometric study of COVID-19 literature in the business and management domain to identify current areas of research and propose a way forward. This paper differs from the present research work for the applied methodology, a bibliometric study, and for the time span analyzed (the authors study the literature published from 1 January 2020 to 11 May 2020). Furthermore, the aim of the authors is to analyze the impact of COVID-19 on overall business, technologies, supply chain management, and the service industry. While the second paper analyzed [19] carries out a systematic review of the literature but focus on "Supply chain" in particular. So, a field of managerial analysis but referred to a specific aspect.

Our research work differs from the mentioned papers in several aspects.

First, the paper attempts to offer a broader view of the subject. Compared to the first paper, the time horizon of analysis of the published papers is extended (see below for more details). Moreover, the topic that emerge are not only analyzed individually but also compared with each other for a synergistic view (see RQ2 for more details). Additionally, the present work does not aim to analyses the impact of Covdi-19 but to observe which management issues are linked to it. Coming to the second paper, our research offers a general analysis on COVID-19 management, not limiting the observation to one aspect (in this case the Supply Chain). From this preliminary analysis it is possible to deduce that there is a lack of recent research that analyses, through a systematic review of the literature, the issue of COVID-19 in the managerial field, offering a broad and recent vision. Starting from the evidence of this gap in the literature, the aim of this paper is to focus attention on the topic of COVID-19 and analyze the state of the art of management literature one year after the start of the pandemic.

Therefore, the following research questions can be put forward:

- $\quad$ RQ 1: What are the main topics developed in managerial literature on COVID-19?

- $\quad$ RQ 2: Are there a common thread and/or intersection between the different topics analyzed?

- $\quad$ RQ 3: What are the main research gaps in management literature and how could future avenues of research be shaped?

The paper is structured as follows. Section 2 exposes and details the methodology used in the systematic review of the literature, highlighting the steps for the research and construction of the database used. Section 3 introduces the main results of the review. In particular, this section is divided into three parts: the first will show the characteristics of the extracted papers, the second part will underline the methodologies used in the papers and the third will focus attention on the main details of the topic. Section 4 shows the discussion of the main results highlighted and provides an answer to the research questions posed. Finally, Section 5 concludes the paper with some considerations, practical and theoretical implications, limitations, and future avenues of the research.

\section{Materials and Methods}

Following the approach to systematic literature review of different authors like Merli et al. [20] and Sassanelli et al. [21], the Elsevier's Scopus database has been selected for the research because it is considered "a major reference database holding more than 50 million literature entries from around 5000 publishers" [22] (p. 1). This systematic 
literature review was carried out from the 7th of January to the 10 February 2021. The extraction of the papers from Scopus was carried out on the 7 January. Figure 1 represents the logical scheme of the systematic review conducted, highlighting the steps and their logical sequentially in order to structure a reasoned and replicable process. The analysis was articulated by a series of steps (described below) that allowed the construction of a database containing the characteristics of the selected papers. From the database, it was possible to elaborate the information, using various points of view. This provided a broad overview of the characteristics of the international literature on COVID-19 in management studies.

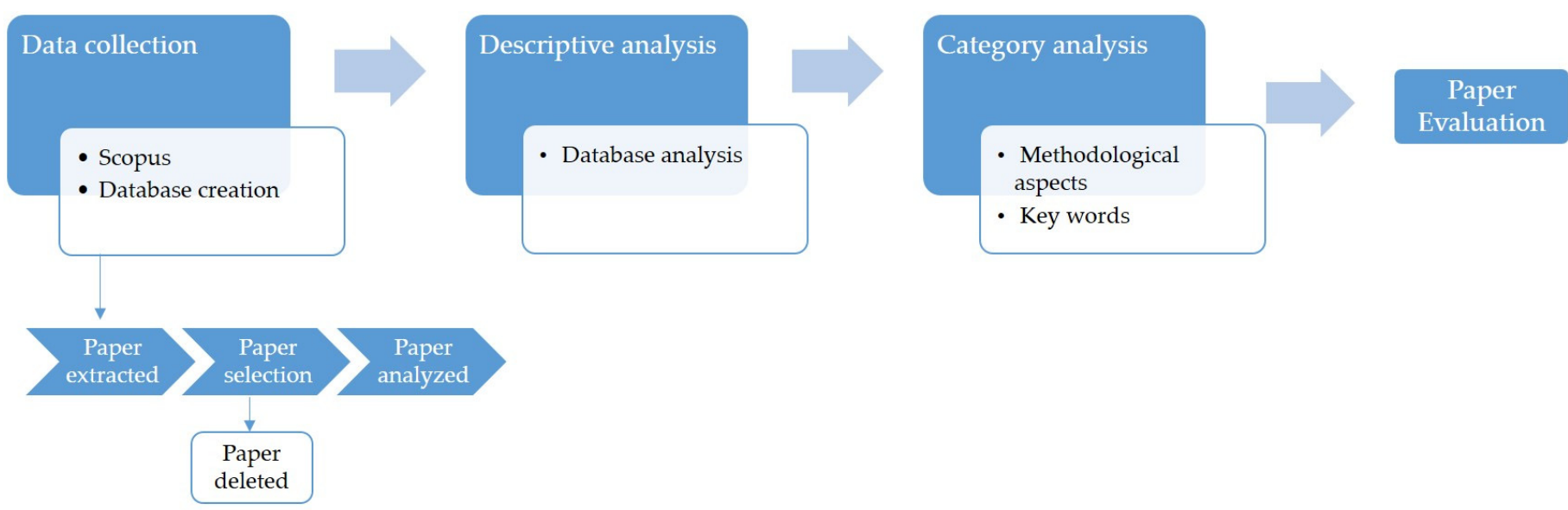

Figure 1. Research design. Source: own elaboration.

First of all, the keyword has been selected. Only the word "COVID-19" was selected, the most used to refer precisely to the topic to be analyzed. Indeed, from the analysis of some systematic reviews of the literature in the medical field, the word "COVID-19" is the most relevant to the study of the current topic linked to the pandemic [23,24]. The search revealed 66,804 papers. Subsequently, the papers were skimmed by applying the thematic filters present on Scopus; in particular, to emphasize the analysis on managerial studies, it was decided to use the filter "Accounting, business, management" the papers highlighted were 1485. From the pre-selected papers, we decided to focus on contributions that responded to four characteristics:

- Article;

- Final publication;

- Journals;

- English language.

These characteristics excluded papers that could have less scientific rigor (i.e., such as book, chapters and/or conference documents). According to this selection the remaining papers are 777. The thematic filter available on Scopus is very wide (Accounting, business, management) so a refinement of the paper selection was carried out to come at the selected ones using the "C-I-M-O framework" [25] to define the specific research focus, excluding papers that do not correspond to the purpose of the review.

The inclusion/exclusion criteria using in the C-I-M-O framework the are

- Inclusion criteria: all the papers related only to the research area about firm, company, enterprises in their management aspects (i.e., marketing, planning, strategy, organization, innovation, resources management).

- Exclusion criteria: all the papers that do not focus precisely on the inclusion criteria. For example, papers excluded deal with technical finance aspects, fiscal topic, medical technical aspects, law, and political aspects, economic in general, religious, sport communication, public operator, leisure management, education, and physical effects on people have been removed. 
Last, 159 have been selected by reading the abstract that made it possible to exclude papers selected in the previous step but which, when analyzed in depth, were not focused on the purpose of the review. The final 159 papers were downloaded from Scopus and organized in a database including details as: first author country; years of publication, journal, research design, and research method details. The construction of this database is fundamental for the subsequent analysis of the papers and to extract the information useful to provide answers to the research questions posed.

Table 1 explains an overview of the research step followed.

Table 1. Overview of the research.

\begin{tabular}{cc}
\hline Research Step & No. Papers \\
\hline Research keywords "COVID-19" & 66,804 \\
Thematic filter "Accounting, business, management" & 1485 \\
Publication type "Article" & 1117 \\
Publication stage "Final publication" & 818 \\
Publication Source "Journal” & 777 \\
Language "English" & 777 \\
C-I-M-O framework & 176 \\
Abstract reading & 159 \\
\hline
\end{tabular}

Source: own elaboration.

\section{Results}

For greater clarity of presentation, the analysis of the results was divided into three sections. In the first, the main descriptive aspects of the database created were analyzed.

The second section focused on the category analysis with methodological aspects of the papers and keywords. Finally, the third section focused on the paper evaluation with the analysis of the main topic studied in management literature, in order to understand the research orientation and the main observation lenses used by scholars. The analysis indicates the existing gaps in literature and identifies future avenues of research in the COVID-19 management domain.

\subsection{Descriptive Analysis: Database Analysis}

The database allowed the extrapolation of some interesting information, even at a general level. The first element analyzed is the year of publication of the selected papers. The prevalence of papers is published in 2020 (133 paper, 84\% of the sample), the year of development of the pandemic, while a part of the paper is in 2021 (26 papers, 16\% of the sample). This result also comes from the timing of data extraction (7 January 2021).

An interesting aspect is the average publication times of the papers relating to the COVID-19 field. Indeed, Kun [26] (2020) states that the publication time of papers relating to papers that study COVID-19 has been significantly reduced compared to the standard review and acceptance times. It is for this reason that, despite being a very recent topic, it already sees a certain amount of published contributions. Subsequently, the journals in which papers are published were analyzed (See Appendix A). The analysis shows a broad scientific collocation of the papers. Some journals emerge from the analysis: IEEE Engineering Management Review (15 papers, 9.4\%), International Journal of Hospitality Management (14 papers, 8.8\%), and Journal of Business Research (10 papers, 6.3\%). The journals in which the papers are published already offer a general overview of the topics being analyzed. For example, tourism, innovation, sustainability, marketing, etc. Finally, in this first phase of research, the geographical origins of the first author of each paper were analyzed.

As Figure 2 shows, the USA (25 papers, 15.7\% of the sample) are the country that contributes most to management research related to COVID-19. The UK follows (18 papers, $11.3 \%$ of the sample) and China (14 papers, $8.8 \%$ of the sample). Analyzing the aggregated data by continents we observe how Europe provides numerous reflections on the issue (21 papers, 13\% of the sample). An explanation of the relevance of the USA, China, and 
Europe can be given by the strong resonance that COVID-19 had for the initiation and subsequent development of the pandemic in these contexts.

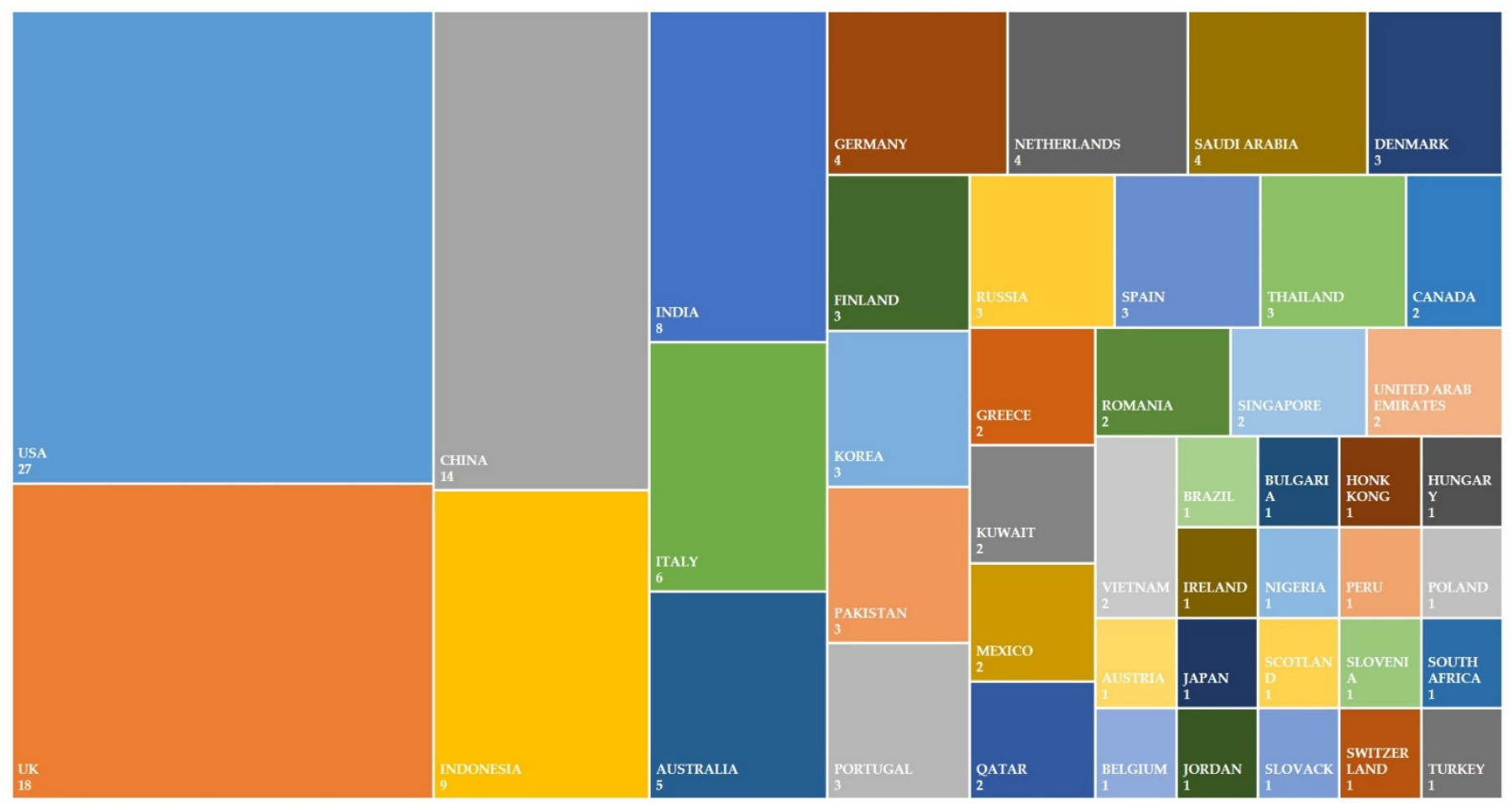

Figure 2. Affiliation country of the first author. Source: own elaboration.

\subsection{Category Analysis: Methodological Aspects of the Selected Paper}

The second analysis step focuses attention on the methodological characteristics of the papers. First of all, the type of research developed was analyzed, distinguishing between empirical and conceptual study. The analysis shows a slight prevalence of empirical papers (88 paper, $55 \%$ of the sample) compared to conceptual ones (71 paper, $45 \%$ of the sample). By focusing on empirical studies, it was found that those of a quantitative (57 paper, $65 \%$ of the sample) nature rather than qualitative ones (31 paper, 35\% of the sample) emerge. Looking in depth at the research methodologies applied in the quantitative papers, the Table 2 shows the main results that emerged.

Table 2. Quantitative research details.

\begin{tabular}{ccc}
\hline Quantitative Research & No. Papers & $\%$ \\
\hline Survey & 44 & $77.2 \%$ \\
Mathematical Model & 10 & $17.5 \%$ \\
Comparative Analysis & 1 & $1.8 \%$ \\
Event Study Method (ESM) & 1 & $1.8 \%$ \\
Multiple Regression Analysis & 1 & $1.8 \%$ \\
Total & 57 & $100 \%$ \\
\hline
\end{tabular}

Source: own elaboration.

Surveys are the most widely used tool and this result can lead to hypothesize how researchers have tried to understand directly from the subjects involved (firms, managers, consumers, etc.) the extent of the pandemic on management issues. In addition, the survey results of 34 paper are combined by the authors with different statistical methods. In particular: sixteen papers (47\%) applied structural equation model (SEM), six papers (18\%) use the survey results in descriptive statistic, six paper $(18 \%)$ implement a factor analysis, three paper (9\%) carry out a partial least squares structural equation modelling (PLS-SEM), 
one paper (3\%) use a cluster analysis, one paper $(3 \%)$ carries out a descriptive statistic and correlation analysis and last one paper (3\%) uses a combination of factor analysis, correlation analysis, structural equation modeling, and hierarchical regression. While, as shown in Table 3, the conceptual papers are prevalent performed on literature review (33 paper, $46 \%$ of the sample) and theoretical framework (22 paper, $31 \%$ of the sample).

Table 3. Conceptual research design.

\begin{tabular}{ccc}
\hline Conceptual Research Design & No. Papers & $\%$ \\
\hline Literature Review & 34 & $48 \%$ \\
Theoretical Framework & 22 & $31 \%$ \\
Commentary & 6 & $8 \%$ \\
Critical Literature Review & 5 & $7 \%$ \\
Bibliometric Analysis & 1 & $1 \%$ \\
Conceptual Approach & 1 & $1 \%$ \\
Integrative Literature Review & 1 & $1 \%$ \\
Systematic Literature Review & 1 & $1 \%$ \\
Total & 71 & $100 \%$ \\
\hline
\end{tabular}

Source: own elaboration.

As Table 4 shows, the authors use different conceptual research design, in particular different types of literature review. Some clarifications may help the understanding of the different approaches adopted in the papers. In particular, according to the

- Literature review, authors describe published materials which provide an examination of recent or current literature [27];

- Critical Literature review, authors aim to demonstrate that the writer has extensively researched the literature and critically evaluated its quality. It goes beyond mere description of identified articles and includes a degree of analysis and conceptual innovation [28];

- Bibliometric analysis, authors offer a statistical evaluation of published journal papers extracting measurable data through statistical analysis of published research studies [29];

- Integrative literature review, authors review, critique, and synthesize representative literature on a topic in an integrated way such that new frameworks and perspectives on the topic are generated [30];

- Systematic literature review, authors provide a comprehensive, transparent, and unbiased review of the literature undertaken according to a clearly defined and systematic approach [31].

The different approaches used by the authors allow to understand how the new topic is analyzed from various perspectives and with different approaches that can contribute to increasing the knowledge and considerations of researchers about COVID-19 in management literature. Simultaneously, the classification confirms what was stated in the introduction to the paper regarding the lack of systematic research on the topic analyzed useful to have an objective and quantitative view of the study of literature (indeed only two papers implementing respectively a systematic literature review and bibliometric analysis).

\subsection{Category Analysis: Keyword Analysis}

A keyword co-occurrence analysis was also carried out as part of the category analysis. The analysis was performed through the use of the VOSviewer software [32,33].

Keyword co-occurrence is an interesting research method to identify research topic [34] and the network created with this method can explain the knowledge structure and the relationship between keywords [35]. The nodes created in the representation represent keywords, while edges represent co-occurrence relationships among nodes.

Therefore, this analysis and its representation allow to understand the keywords most used by the authors and shared, as well as the relationships between the various research 
themes analyzed. Figure 3 shows the representation of the keyword co-occurrence analysis using the binary counting and only keywords that repeated at least three times [36].

Table 4. Keywords cluster.

\begin{tabular}{ccc}
\hline Cluster $\mathbf{1}$ & Cluster $\mathbf{2}$ & Cluster 3 \\
\hline COVID-19 & COVID-19 & Consumption Behaviour \\
Coronaviruses & Crisis & Coronavirus \\
Digital Transformation & Digitalization & Disease Spread \\
Engineering & Dynamic Capabilities & Economic Impact \\
Management & Entrepreneurship & Tourism \\
Managers & Global Supply Chain & Tourism Economics \\
Pandemic & Global Value Chain & Tourism Management \\
SMEs & Lockdown & Tourist Behaviour \\
Supply Chain & Resilience & Viral Disease \\
Sustainability & Supply Chain Management & - \\
Sustainable Development & Supply Chain Risk & - \\
Technology & - & - \\
Cluster 4 & Cluster 5 & Cluster 6 \\
\hline Air Transportation & Artificial Intelligence & Corporate Social Responsibility \\
China & Consumer Behaviour & Innovation \\
Crisis Management & COVID-19 Pandemic & Marketing \\
Epidemic & Employment & - \\
Respiratory Disease & Leadership & - \\
Strategic Approach & Social Distancing & - \\
Travel Behaviour & - & - \\
\hline Soure: own elaboration & &
\end{tabular}

Source: own elaboration.

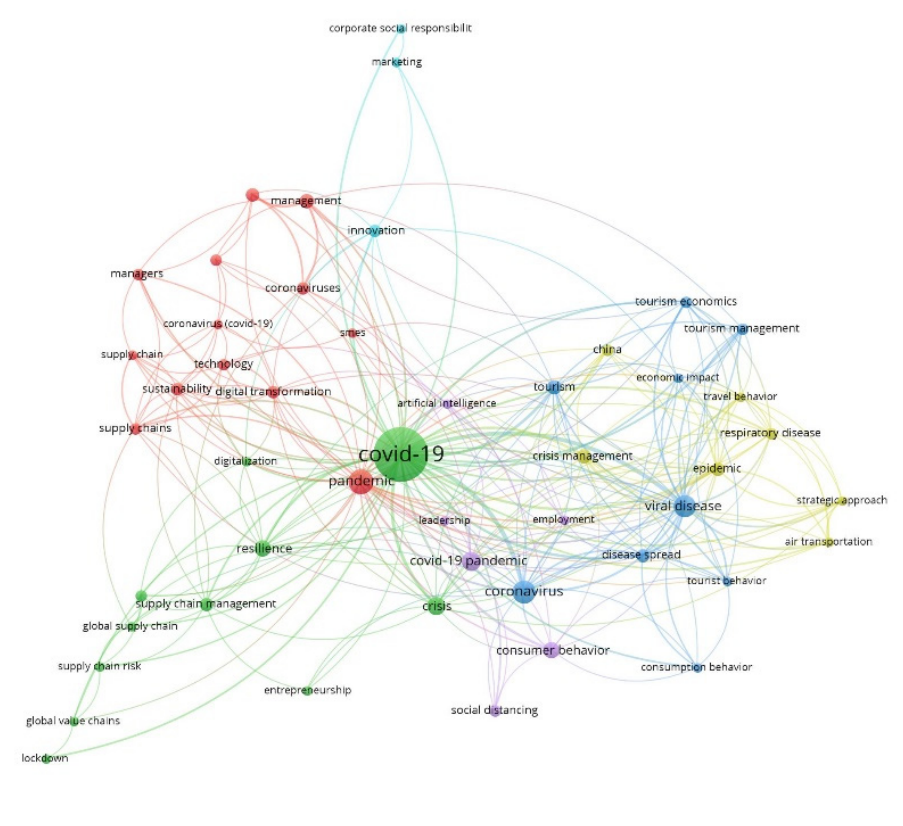

Figure 3. Keyword co-occurrence analysis network. Source: own elaboration with VOSviewer.

The most used keywords are COVID-19 with 91 occurrences, Pandemic with 19 occurrences, Coronavirus 17 occurrences, Viral disease 15 occurrences, etc. (See Table A2 for more details.) In particular, the size of the label and the marker of a key word is determined by the weight of the item. The higher the weight of a keyword, the larger the label and the marker of the item. Obviously the most used word is COVID-19, the core keyword for the study of the pandemic (green circle). Moreover, the lines between different keywords represent the links. Numerous categories of analysis branch off from 
the central key word, which partly anticipate the subsequent study of the topics (i.e., innovation, digital, and consumers). The analysis highlights 6 main clusters in which the keywords are grouped in terms of combinations (see Table 4). In each cluster appears one or more terms referring to the pandemic (i.e., Coronavirus Disease, Coronavirus, and Epidemic) with related keywords that highlight the orientation of the studies in a first vision (i.e., marketing, strategy, supply chain, and consumers). Cluster 1 is the one that contains the largest number of keywords and highlights the connection between digital transformation, management, sustainability, and pandemic management. Cluster 2 focus mainly on supply chain management. Cluster 3 reports on some aspects of tourism as well as Cluster 4 focused on air transport. Cluster 5 seems consumer-oriented while Cluster 6 analyses Corporate Social Responsibility (CSR) and the links with innovation and marketing. From the analysis of the clusters it is possible to state that keywords linked to the topic of innovation are recurrent (highlighted in italics in the table). Subsequent analyses will further underline this evidence.

\subsection{Main Topic Emerged from the Selected Paper}

The third level of the analysis allowed to focus attention on the topics studied by the various papers. Table 5 shows the results that emerged from the detailed analysis of the papers. The topics were defined using an inductive approach [37] moves from the specific to general [38] and by combining the reading of the papers with the results of the previous key-words analysis (See Section 3.3). The inductive approach is very useful because it provides categories from the raw data without the use of any theory-based categorization matrix, as is the case with the deductive approach [39]. Resulting categories indicate the main general topic of the papers. Each paper is placed in only one topic.

Table 5. Main topics.

\begin{tabular}{cccc}
\hline Topic & No. & $\mathbf{\%}$ & References \\
\hline Tourism & 21 & $13.2 \%$ & {$[40-60]$} \\
Innovation & 20 & $12.6 \%$ & {$[61-80]$} \\
Human Resources (HR) & 17 & $10.7 \%$ & {$[81-98]$} \\
Strategy & 17 & $10.7 \%$ & {$[99-115]$} \\
Consumers & 15 & $9.4 \%$ & {$[116-130]$} \\
Supply Chain & 14 & $8.8 \%$ & {$[131-144]$} \\
Small Medium Enterprises (SMEs) & 12 & $7.5 \%$ & {$[145-155]$} \\
Marketing & 10 & $6.3 \%$ & {$[156-165]$} \\
Sustainability & 8 & $5.0 \%$ & {$[166-173]$} \\
Corporate social Responsibility (CSR) & 6 & $3.8 \%$ & {$[174-179]$} \\
International Markets & 6 & $3.8 \%$ & {$[180-185]$} \\
Impact on Firm & 5 & $3.1 \%$ & {$[186-190]$} \\
Production & 4 & $2.5 \%$ & {$[191-194]$} \\
Communication & 2 & $1.3 \%$ & {$[195,196]$} \\
Knowledge & 2 & $1.3 \%$ & {$[197,198]$} \\
Total & 159 & $100.0 \%$ & - \\
\hline
\end{tabular}

Source: own elaboration.

As can be deduced from the classification that emerges, the extent of the scope of the COVID-19 issue can be linked to many managerial areas, strictly or not connected to business management.

An interesting insight is provided by the Pareto analysis. This analysis is a statistical method which ranks the data classifications in decreasing order from the highest frequency of occurrences to the lowest frequency of occurrences [199]. The total frequency is summed up to 100 . The Pareto analysis based on the $80 / 20$ rule principle and the data classifications are divided into two categories: the "vital few" items occupy a substantial amount (80 per cent) of cumulative percentage of occurrences and the "useful many" occupy only the remaining 20 per cent of occurrences [200]. The Pareto analysis is born as Quality Control tool of processes, but several authors used this tool in the systematic literature 
review (e.g., [199-201]). Table 6 show the results of the Pareto analysis. The analysis allows to focus attention on the topics that can be considered most relevant in the systematic review conducted. Specifically: Tourism, Innovation, HR, Strategy, Consumers, Supply Chain, SMEs, and Marketing. This result is consistent with some considerations that have already emerged in the literature regarding the areas most affected by the pandemic [202].

Table 6. List of topics "Vital Few" (80 percent).

\begin{tabular}{cccc}
\hline Topic & $\begin{array}{c}\text { Frequency of } \\
\text { Occurrence }\end{array}$ & $\begin{array}{c}\text { Percentage of Frequency of } \\
\text { Occurrence }\end{array}$ & $\begin{array}{c}\text { Cumulative } \\
\text { Percentage }\end{array}$ \\
\hline Tourism & 21 & $13 \%$ & $13 \%$ \\
Innovation & 20 & $13 \%$ & $26 \%$ \\
HR & 17 & $11 \%$ & $37 \%$ \\
Strategy & 17 & $11 \%$ & $48 \%$ \\
Consumers & 15 & $9 \%$ & $57 \%$ \\
Supply Chain & 14 & $9 \%$ & $66 \%$ \\
SMEs & 12 & $8 \%$ & $74 \%$ \\
Marketing & 10 & $6 \%$ & $80 \%$ \\
Useful Many & 33 & $20 \%$ & $100 \%$ \\
\hline
\end{tabular}

Source: own elaboration.

\subsection{Sub Topic Details}

Given the number of topics that emerged from the literature review conducted, it appeared necessary to investigate the individual issues in order to fully understand the details and main problems faced by the authors. Therefore, the topics have been divided into sub-topics to better appreciate the contribution and the study presented (see Table 7). The first topic that emerged from the analysis is that of "Tourism". By investigating the papers in detail, it was possible to identify five sub-topics relating to this subject. Table 7 shows the detail. A substantial part of the papers examined (nine papers, $43 \%$ of the sample) focus on the analysis of the impacts of the pandemic on the tourism sector and on the evaluation of a possible trend and future scenarios for firms operating in this area. At the same time, the study of possible solutions to the crisis in the sector also assumes considerable importance (eight papers, $38 \%$ of the sample). The other papers deal with even more specific aspects of the tourism field; interesting are the studies on consumer reactions to the new tourism scenarios dictated by the pandemic (two papers, $10 \%$ of the sample). The second topic that emerged from the analysis is "Innovation". In this context, as Table 7 shows, ample space is given to the analysis of the challenges and opportunities deriving from the use of innovations (seven papers, $35 \%$ of the sample). The second sub-topic, on the other hand, focuses more precisely on the innovations of Industry 4.0 (five papers, $25 \%$ of the sample) and their contribution to the management of firms in a pandemic.

The topic of "Human resources" sees a concentration of studies on the effect (12 papers, $71 \%$ of the sample) that the spread of COVID-19 has had on workers and their management in terms of performance ( 3 papers, $18 \%$ of the sample) and organization ( 2 papers, $12 \%$ of the sample).

The topic of "Strategy" is very broad.

Indeed, in this context, the papers analyze various aspects and implications deriving from the effect of the pandemic on strategic business decisions. Particularly relevant is the analysis of planning (11 papers, $65 \%$ of the sample) which represents the most frequently addressed sub-topic.

About "Consumers" the study assumes a strategic role in the analysis of the pandemic from a managerial perspective. The papers show considerable interest in the study of consumer perceptions (eight papers, $53 \%$ of the sample) and subsequent behaviour (three papers, $20 \%$ of the sample) in the face of the new economic scenario. 
Table 7. Sub Topic details.

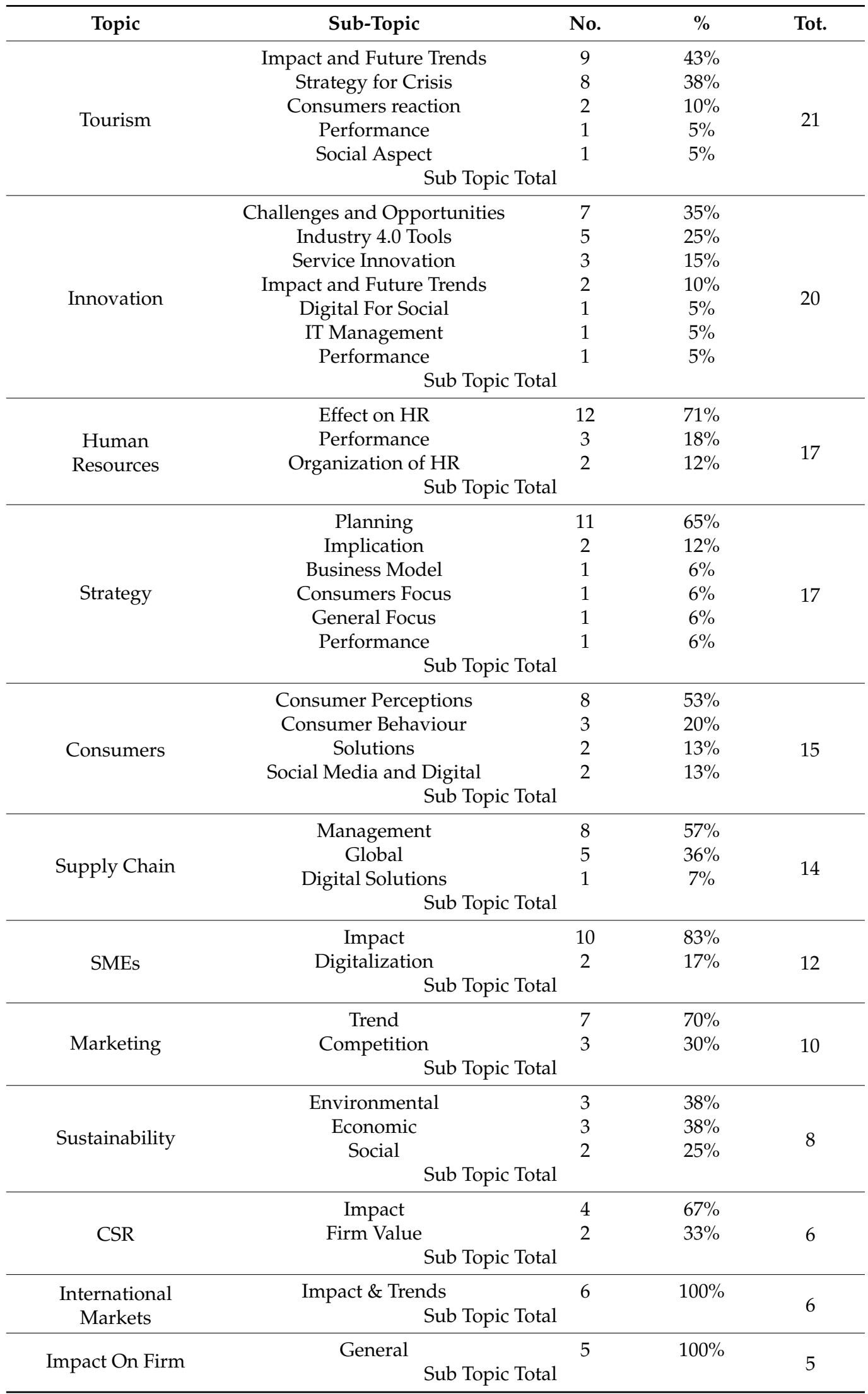


Table 7. Cont.

\begin{tabular}{|c|c|c|c|c|}
\hline Topic & Sub-Topic & No. & $\%$ & Tot. \\
\hline \multirow{4}{*}{ Production } & Efficiency Effects & 2 & $50 \%$ & \multirow{4}{*}{4} \\
\hline & Coproduction & 1 & $25 \%$ & \\
\hline & Market Barriers & 1 & $25 \%$ & \\
\hline & \multicolumn{2}{|c|}{ Sub Topic Total } & & \\
\hline \multirow{3}{*}{ Communication } & Misinformation & 1 & $50 \%$ & \multirow{3}{*}{2} \\
\hline & Trend In Communication & 1 & $50 \%$ & \\
\hline & Sub Tor & & & \\
\hline \multirow{2}{*}{ Knowledge } & Management & 2 & $100 \%$ & \multirow{2}{*}{2} \\
\hline & \multicolumn{2}{|c|}{ Sub Topic Total } & & \\
\hline \multicolumn{4}{|c|}{ Total } & 159 \\
\hline
\end{tabular}

Source: own elaboration.

From the "Consumer" analysis, the focus shifts to more technical and organizational aspects of business management with a focus on the "Supply chain". In this context, the contributions of the various researchers focus attention on a new articulation and management of the chain in relation to the new dynamics and needs of markets, especially global. Further, in this case, as already seen for the topic Innovation, attention is paid to digital solutions and their support in adapting the supply chain to the new global context.

Continuing the analysis, the topic of "SMEs" offers some relevant insights for thought, especially relating to the impact of the pandemic on the management and survival of these firms ( 10 papers, $83 \%$ of the sample). While, the remaining two papers ( $17 \%$ of the sample) shift attention to the issue of digitization already extensively investigated in the literature (i.e., [203,204]) and which has certainly had a boost in acceleration over the last year. The last relevant topic highlighted by Pareto's analysis is "Marketing".

The focus given by the researchers in the papers is related to the study of the trends (seven papers, $70 \%$ of the sample) of the marketing discipline in the light of new market dynamics and above all of consumers. Furthermore, some authors focus their attention on the new competitive scenarios that may emerge (three papers, $30 \%$ of the sample).

The remaining topic fall within the $20 \%$ identified through Pareto's analysis and although they have a lower impact on our research, they still deserve a detailed and in-depth analysis like the previous ones. Primarily the topic of "Sustainability".

Indeed, from the analysis it emerges that eight papers focus on sustainability in the managerial analysis of the pandemic. For a better understanding of the issue, the lens of analysis used was that of the three pillars of sustainability: economic, social, and environmental. Table 7 highlights the subdivision of the papers into the three pillars of sustainability [205]. Environmental and economic aspects are the most emerged, even if the social aspect of sustainability gets a fair amount of interest from researchers.

In the context of "CSR", the papers study the impact (four papers, $67 \%$ of the sample) of the pandemic on the application of corporate social responsibility and what can be reflected in terms of value for firms (two papers, 33\% of the sample). Continuing the analysis, in relation to the topic of "International markets" all the papers (six papers, 100\% of the sample) reveal a concentration of the study on the development trends of global markets with consequent evaluation of the impacts on the management of firms, especially those so-called "born global" [206].

The topic "Impact on firms" collects all those contributions that evaluate a possible impact of the pandemic on firms in a general vision (five papers, $100 \%$ of the sample), without addressing a specific area and/or activity of the managerial environment. Indeed, as has so far emerged from the other topics, the sub-topic "Impact" is traceable but linked in a specific manner to a topic analyzed (i.e., Tourism and Innovation topics).

An interesting focus derived from the topic "Production" which goes into detail on the consequences of the pandemic on the technical management of production companies. In this context, the research focuses on the study of efficiency, Coproduction and Manu- 
facturing process. Finally, the topic of "Communication" focuses on misinformation (one paper, $50 \%$ of the sample) and future trends in communication dynamics (one paper, $50 \%$ of the sample) while that of knowledge is totally focused on management (two papers, $100 \%$ of the sample). Table 7 summarizes the sub-topic that emerged from the analysis.

\section{Discussion}

The results that emerged allow to formulate some initial considerations on this broad and new field of research. In particular, the first research question put forward in the introduction of the paper was the following:

RQ1: What are the main topics developed in management literature on COVID-19?

With regard to the topics covered in the papers, a very broad panorama emerges. In fact, 15 different topics were found in the 159 papers analyzed. Pareto's analysis offers an opportunity to highlight the most important topics among those that emerged (see Table 6). "Tourism" is one of the areas most affected by the pandemic with huge effects when compared to other dramatic events of the last few years (for example, 11 September 2001) [58]. As affirmed by Sobaih et al., [43] (p. 1), "tourism industry is one of the hardest hit by this pandemic since it is one of labor-intensive industries with millions of workers at risk. Additionally, the fundamental people-to-people nature of tourism makes it more vulnerable and adds more difficulties to adapt to this pandemic." Moreover, tourism is an area with different impacts and implications for the future because of its heterogeneity, just think of the variety of demand, for instance, leisure travelers, group and single tourists, religious tourists, business travel, and so on [58]. In the context of the various aspects dealt with (see Table 7) it is important to underline how it is crucial to envisage strategies to face the difficulties of the pandemic that focus attention directly on consumers and their "travel fear" [44]. Indeed, the three main sub-topics that emerged (impact and future trends, strategy for crisis, and consumer reaction) highlight a common thread: the strategic consumers' management of their travel fear. This link also emerges clearly from the analysis of key-words occurrences carried out (See Table 4). The keywords that emerged in Cluster 4 anticipate precisely this consideration. In the cluster are highlighted the keywords: air transportation, crisis management, strategic approach, and travel behaviour.

Cluster 3 also provides important insights. Here too, aspects relating to consumption behaviour and tourist behaviour are highlighted for the management of tourism and the impacts and consequences of the pandemic. In particular, travel behaviour is expressed by different authors as "travel fear" that should make it possible to understand the consumer's orientation, and his motivations for behaviour. Travel fear can orient the crisis strategy of firms, and thus open up future scenarios and trends. Thus, some authors state precisely that managing the fear and psychological aspects of potential travelers must be the key to overcoming the crisis in the tourism sector [52]. The strategy adopted by firms of tourism must be communication-oriented, with a problem-focused and/or emotion-focused approach [44] and in this sense an interesting support can come from technology. Indeed, some authors suggest that for the future development of strategies for the tourism sector, and especially for hotel management, the use of artificial intelligence tools and robotics can be of support [50]. In particular, these tools can help in implementing and communicating the orientation to hygiene and cleanliness with respect to issues that have been considered in pandemic outbreaks as a culprit of disease. Thus, when predicting the hotel industry's recovery post-COVID-19, these aspects must be focal points given the severe effects of this pandemic and hotel guests higher safety-related expectations during travel [50]. Furthermore, Dimitrios et al. [47] reconsider the strategic tools that the hotel industry can use in this moment and mainly highlight the ensuring safety for the guests, the use of new technology for strengthening guest relationships and satisfy clients' needs and also to provide a "financial pillow" to support any continuation of the pandemic. This is also crucial in the airline industry. Indeed, a strategy to cope with the crisis and revive the air travel sector, must include not only a short-term orientation (reduction of flight prices), but also a strategy aimed at reassuring passengers that flying is safe and encouraging them to 
return to the air through orientation to hygiene and cleanliness (i.e., temperature checks, face masks, social distancing, ultra-violet cleaning of aircraft cabins, security screening trays, and search areas have all been suggested as a way of safeguarding travelers and staff) [46]. Obviously, as some authors suggest, alongside the strategies adopted by companies in the sector, it is also essential for governments to intervene in order to rebuild public confidence also through cooperation and encouraging the introduction and use of advanced technology [55].

Among the strategies to increase tourism and counteract travel fear, Kock et al. [52] suggest orienting the offer towards group travel and/or new travel insurance solutions that provide the tourist with a feeling of security by reducing fear and the feeling of risk. The authors emphasize the importance of not feeding the fear of travelling with the necessary social distance, which is a valuable health tool for fighting the pandemic and stress the importance of the social aspect of the tourists and the consumers in general.

These latter considerations highlight the social aspect of tourism that emerges from the sub-topics identified. The social aspect of tourism is also carefully observed and analyzed from different points of view, especially in relation to the strategies adopted to overcome the crisis. Some authors consider the social costs of tourism during the pandemic [56] highlighting a strong involvement of consumers and citizens to support the recovery of tourism. The authors highlight how a crisis invariably brings out the best in residents in terms of values and responsible behaviour and how consumers are willing to pay more to maintain public health and reduce the infection risk from tourism activity.

Moreover, some authors state social aspect of tourism as an opportunity arising from the pandemic. In particular, the COVID-19 and the related world crisis have increased the focus on social values and in particular on the creation of tourism social ventures aiming to create social value, solve social problems created by the pandemic and provide help to people in need [58].

In addition, according to a social and environmental perspective, the pandemic prompts further reflections on the dynamics of tourism in the future. Indeed, it is important to discuss over-tourism in metropolitan destinations in favor of a more balanced approach with sustainability-oriented strategies [51]. In the light of these considerations, the topic of tourism appears very broad and complex, and the sub-themes are interconnected. The new strategies to be devised and implemented must take into account all aspects of the consumer and sustainability in its three aspects: environmental, social, and economic.

The second most discussed topic is that of "Innovation". Indeed, innovation has played a fundamental role in the management of the pandemic and as emerges from the results it is reflected in various areas of company management. Fernando et al. [71] affirm that COVID-19 has accelerated the processes of digital transformation in firms and many authors underline the importance of this process in view of new challenges and opportunities [61,78]. Innovation can support, for example, the development of work at home and smart working [61] also paying attention to the social aspect of these new ways of working [65]. The enabling technologies of Industry 4.0 play an important role in this innovative development [207]. Indeed, the Internet of Things, artificial intelligence, and block chain are mentioned in providing valid support in facing the difficulties that emerged at the management level with the pandemic [70,74,75]. An interesting study is that of Chesbrough [69] which underlines the role of "Open Innovation" in this context. The author underlines how the crisis situation must push firms and institutions to evaluate the opportunities for opening and sharing innovation for the development of joint and advanced solutions (i.e., encourage firms and universities to release portions their intellectual property). In the light of the above, even the topic of innovation also has a strong link with that of tourism. For instance, technology innovation can help to alleviate customers' perceived health risks, also in tourist services. Different technologies such as contactless systems, face recognition systems, and cleaning robot systems, can reduce interaction with employees, and reassure consumers, including from the mentioned travel 
fear [79]. The pandemic highlighted a new key to the understanding innovation, ranging from managerial or employee adoption processes alone to the role of reducing perceived health risk [208].

"Human resources" is another very relevant topic emerged from the review. Workers were hit hard in various ways during the pandemic: organization of work, rhythms and schedules, working, furloughed, or laid-off, psychological well-being, and psychological distress [83]. Some authors therefore considered it important to focus the study on human resource management in moments of uncertainty and difficulty such as the current one $[81,90]$. The new organization of work is also an important aspect. Indeed, the new requirements push firms to organize the dynamics and work patterns also technically, both within firms and from the point of view of working from home [88]. These profound changes, above all organizational changes, also push the need for a review and reassessment of work performance. Cohen affirms, as "companies must pay attention to the factors of e-training, e-leadership, and work-life balance to keep employees motivated and to maintain optimal employee performance, especially during the COVID-19 pandemic through working online" [92] (p. 443). Therefore, the different work dynamics can be suitably motivated and monitored to push workers towards satisfaction and good performance.

The subsequent "Strategy" topic requires us to reflect on the need to completely reread business management starting from planning. Kaushal [41] affirms that firms must redesign/reorganize their activities for post COVID-19 new business, and to achieve this Kashyap [106] emphasizes how necessary it is to identified some critical success factors to help firms in medium and longer-term planning. A new vision of strategies and new parameters is therefore necessary that allow companies to restart their planning paths in a new scenario in a proactive way [113].

With the topic of "Consumers", the analysis focuses on the market and its main players. If, as pointed out, companies have to face numerous challenges and organizational changes, consumers too have seen a severe change in their behaviour and their choices [126]. Consumer perceptions and behaviour are the aspects most investigated in the literature. As affirmed by Sheth, "The COVID-19 pandemic and the lockdown and social distancing mandates have disrupted the consumer habits of buying as well as shopping. Consumers are learning to improvise and learn new habits [ . . ] new habits will also emerge by technology advances, changing demographics and innovative ways consumers have learned to cope with blurring the work, leisure, and education boundaries" [129] (p. 280). In this perspective, the importance of innovation is again underlined, according to Kim "managers could adapt to the digital transformation of the market to recover or even further increase sales after COVID-19" [209] (p. 212).

Therefore, technological innovations can be of support for companies in analyzing, monitoring and managing new consumer behaviors, their reactions [125], as well as panic buying [128]. This last aspect is closely linked to the growing use of social media during the pandemic. Naeem [117] states that this tool, also due to the numerous information and fake news available in real time, leads consumers to impulsive, accumulation and non-rational purchases.

The "Supply chain" is the sixth important issue that emerges, and it too represents one of the topic most strongly affected by the pandemic since the first events that occurred. Indeed, COVID-19 was first identified and reported in Wuhan, China, in December 2019. It was then reported in other parts of China, and other countries [142], severely affecting the dynamics of global supply chains [138]. The supply chains have literally been blocked due to the lock-downs of the various States and this has highlighted their fragility and dependence on some areas (i.e., China). The studies analyzed focus on a new management and construction of supply chains in order to be able to foresee and appropriately deal with any blocks and impediments deriving from external factors in the future. For example, Sharma et al. [134] define the "next-generation supply chain" highlighting the necessary changes to the current structure and management of the chains. The authors recommend firms adopt a forward-looking approach that includes analysis of people, processes, and 
technology to improve the next-generation supply chain; also, in this context, the technological innovations can give an important support. Indeed, Quayson et al. [140] argue the need for a "critical digital transformation for building a resilient and sustainable post-COVID-19 supply chains for developing countries" not only for multinational companies but also for small firms operating globally.

In this regard it is interesting to analyze the context of "SMEs", another topic that emerged from the literature review. In this context, most authors study and investigate the impacts of the pandemic on the management of these companies. Although SMEs have characteristics that make them flexible and resilient to crises and external factor, COVID-19 has also led to profound problems for this category [19] (p. 104).

The papers highlight issues in the management of human resources and employment [145,149] in economic sustainability [147] and in business in general [146,152].

As already highlighted in the previous topics, innovation comes into play in the management of the pandemic in SMEs. Indeed, Effendit et al. [148] and Guo et al. [150] affirm the usefulness of digital tools, such as social media, and digitization in general to support SMEs in the new needs dictated by COVID-19. Guo et al. state that "digitalization has enabled SMEs to respond effectively to the public crisis by making use of their dynamic capabilities [...] digitalization can help improve SMEs' performance" [150] (p. 1).

Finally, the last relevant issue to emerge from Pareto's analysis is "Marketing".

This topic, like that of consumers, is closely linked to the changes in the market that occurred with the pandemic. It is interesting the statement of He and Harris who argue that "organizations reflecting on the post-pandemic world will need to re-evaluate their visions, missions, and their objectives to account for the changes to their customers, competitors, amongst other shifts. Goals and objectives that incorporate long-term survival, strategic agility, meaningful social responsibility, possibly centered on a societal marketing orientation seem likely" [177] (p. 180).

Therefore, the impact of the pandemic should orient marketing towards a social philosophy and towards sustainability objectives. The new marketing trend is therefore a crucial aspect of study for many authors (i.e., $[159,163,165])$ and some also pause to understand how competitive dynamics in the market will change and how marketing will have to cope with these changes $[158,161]$; also, in this case, the appeal of the topic of Innovation are strong. Indeed, Wang et al. [164] they draw attention to the need to innovate marketing, in particular the strategic one, pushing it towards the search for strategies that have a strong motivational drive for innovation and a level of collaborative innovation.

The other remaining topics, as it emerges from the Pareto analysis, complete the overall vision of the COVID-19 study in the managerial field. Sustainability (eight papers, $5 \%$ of the sample), CSR (six papers, $4 \%$ of the sample), international markets (six papers, $4 \%$ of the sample), impact on firm (five papers, $3 \%$ of the sample), production (four papers, $3 \%$ of the sample), communication (two papers, $1 \%$ of the sample), and knowledge (two papers, $1 \%$ of the sample), are topic that we have already partially found in the discussion of the previous ones (i.e., CSR in marketing details or International markets in supply chain analysis) and will probably undergo considerable development with the deepening of managerial studies on the pandemic.

Sustainability in particular deserves a brief study. In this regard, some recent studies emphasize the need for a redefinition of the concept of sustainability. Hakowirta and Denuwara [210] propose the introduction of another pillar of sustainability, the fourth pillar: human health. The pandemic has brought out new needs and facets of sustainability in addition to the classic three areas observed. Beyond this, in the classic view [211], the papers that emerged from the review focus on economic, social and environmental aspects. From an environmental point of view, great importance is given to the management of waste $[168,170]$ which has seen a significant increase during the pandemic (especially in the hospital sector). From the point of view of social sustainability, the impact of the pandemic underlines the need for a more marked attention to the quality of life in the light of the new rhythms of work and sociality $[166,167]$. Finally, economic sustainability is investigated 
from the point of view above all of hospitals [171] and of the profound difficulties and crises they are going through. Starting from a careful assessment of economic sustainability and business continuity, hospitals should promote an overall sustainable development that supports the recovery not only of the health sector but also of those connected to it (i.e., tourism) [171].

RQ 2: Are there a common thread and/or intersection between the different topics analyzed?

Coming to the second research question, the topics emerged from the literature provide numerous and useful points of contact and joint reflection. The topic of "Innovation" in particular allows a systemic vision between several subjects and represents a common thread. The analysis of the keywords showed a presence of innovation and technology aspects in different papers. Cluster 1, for example, shows the versatility of innovation, particularly digital transformation and technology, in pandemic management. Support for innovation is clear in SMEs both to cope with the crisis, to improve performance in times of crisis [150] and SMEs resilience [143,154]. Innovation is also understood in the way products are marketed, and here some authors emphasize the role of social media as a technology for approaching consumers in times of pandemic [148]. At the same time, the technology supports the development of a supply chain more resilient to external threats. The inclusion of innovative tools (i.e., artificial intelligence, robotics, or deep learning-based tools) can help firms identify and interpret information from markets regarding disruptions and visibility in the supply chain and provide firms with appropriate solutions to help counteract the effects of COVID-19 [134]. Moreover, as some authors point out and Cluster 1 itself shows, it is crucial to integrate innovation from a multidisciplinary perspective [172]. The innovation process that enables companies to tackle the pandemic must also integrate the topic of sustainability and sustainable development [77], and at the same time should involve entrepreneurs in the careful management and engineering design of the firms and its processes [141].

Regarding the subject of innovation, Cluster 2 also provides food for thought. Analyzing the keywords, a similarity emerges with the previous cluster, but it is extended to a global business perspective. Indeed, there are some considerations of global value chain and a global supply chain supported by digitalization [138]. It is clear that the use of innovation will solve some of the problems of global supply chains, i.e., length, concentration in certain geographical areas, lack of transparency and high price sensitivity [132]. At the same time, this digital transformation involves again the consumer, who will have to adapt to contactless exchanges, cheaper supply chains, and focus more on service levels [132]. A further reflection highlights the need of a link and a precise logic connection between the topics of "Innovation", "Human Resources", "CSR", and finally "social sustainability" aspects emerging from the topics analyzed but also from the keyword Clusters 5 and 6. As emerged from the previous analysis, innovation represents the cornerstone to face the new managerial challenges imposed by the pandemic [70], but to implement the innovative process effectively and efficiently it is necessary to consider the reflection on human resources management [92] and the impacts and consequences that this can lead to new work dynamics [64]. Only by trying to combine these aspects, innovation can actually give positive results to management in both small and large companies. The process of digitization of businesses, which has been underway for years, therefore, deserves a new joint vision with aspects relating to the social sphere of business [212].

Furthermore, innovation in the context of the pandemic, drives the development of sales and of human work. Sharma affirms that during 2020 "most technology companies have experienced an increase in demand" [57] (p. 444). In this domain Fernando affirm that "digitization of companies will increase the importance given to the digital channels of marketing and sales of companies. It will also foster teleworking and consumption of technological products as more people will interact using hybrid communication mechanisms accessible from anywhere, and not exclusively in the physical environment of companies and their homes" [71] (p. 101). 
Finally, again on the subject of innovation, the connection with the new consumer dynamics is clear. The development and correct management strategy of social media, for example, can support the management of irrational consumer behaviour, often dictated by the logic of panic [117]. The pandemic has pushed consumers towards new needs and purchasing approaches; innovation can support this change by developing new opportunities and sales channels [127]. In this sense, Kim affirm that pandemic can be considered "as an accelerator of the structural change in consumption and the digital transformation in the marketplace" [209] (p. 212). Looking also at the results that emerged from the analysis of the key words used in the papers (see Table 5), it is clear that four out of six clusters highlight key words relating to innovation (Digital Transformation in cluster 1, digitalization in Cluster 2, Artificial Intelligence in Cluster 5, and Innovation in Cluster 6). It is interesting to note that in Cluster 6, in addition to technologies related to artificial intelligence, there is an explicit link to the employment. This aspect is very important because innovation and technology should not be seen as substitutes for human labor. On the contrary, some authors underline how, in this moment of crisis, there can be a good synergy between workers and technology support [80], in particular, with respect to the reduction of human contact and the potential spread of the virus.

Another interesting guideline in these studies is to pay attention to the social aspect of management that emerge also from Cluster 6 (with the keywords Corporate Social Responsibility, Innovation, and Marketing). In this context of profound global changes, attention to people is fundamental. The human resources must be carefully considered, in the strategy, in the new organization of work and relative performances [83]. The pandemic has brought out very delicate aspects to be taken into consideration even more than what has already been done in the past, for example, attention to the work of women as well as mothers [91].

Marketing must also move towards a greater attention to social issues and the new needs of the consumer. The new marketing strategies must be oriented towards social sustainability and the human aspect of the consumer [158]. So, an ever greater attention to ethics in management is needed, especially for all those aspects strictly connected with man (be it a worker or a consumer) and above all in a long-term vision [177]. Some authors pointed out that in this pandemic phase, the use of social media and other technologies (for example, the we-media) helped firms in communicating CSR to consumers and positively affected brand image [179]. Cluster 6 thus aims to a profound need to rethink marketing, its strategies in supporting and implementing a more genuine and authentic CSR and helping to address urgent global social and environmental challenges $[177,179]$. Therefore, innovation can be the most valid means to face the challenges posed by the pandemic, but it must be an innovation oriented towards the human, social and ethical component of businesses $[65,66]$, in line with the transition already underway between Industry 4.0 and Society 5.0 [213].

RQ 3: What are the main research gaps in management literature and how could future avenues of research be shaped?

The last research question leads us to consider some evident gaps that emerged from the analysis of the papers to stimulate and guide future studies in this area. From an overall evaluation of the papers and the topics covered, it is clear that there is a gap in relation to the business model topic. Indeed, no papers have been proposing or hypothesizing specific business models to be implemented in this pandemic context or also in the post-COVID scenario. There are numerous considerations by the authors on changes and adjustments to business management in specific areas (i.e., HR, Supply chain, marketing, production), but an overall vision seems to be lacking.

This gap may perhaps be related to the fact that the topic is very recent and there is not enough evidence to structure such a contribution. The slight prevalence of empirical studies found (see Section 3.2) could lead to a future implementation of theoretical models and frameworks capable of responding to this gap. Therefore, the organic and global vision 
provided by the systematic review can support in creating a business model that takes into consideration the numerous crucial aspects highlighted.

Another highlighted gap that could be deepened is the application of innovations, especially digital ones, to support the social orientation of companies. As already mentioned, the attention to the new working and consumption needs shift the attention even more to the social and ethical aspects of the business. The technology with its tools (i.e., the numerous enabling technologies of Industry 4.0) could be of support for the transition to new needs. But guidance and support are needed to understand how best to implement digital innovations and tools in realizing new business practices oriented to the principles of Society 5.0.

Finally, a topic still little investigated in the literature is the communication. The new consumption dynamics encountered require firms to focus on marketing (i.e., $[159,163,165]$ ) and above all on communication [195,196]. Communication in particular must help guide and inform the consumer in this new market scenario (from online sales to the proliferation of information disseminated on social networks). For example, appropriate communication dynamics can help the consumer in orienting choices by mitigating highlighted reactions of panic buying.

\section{Conclusions}

The systematic review of the literature conducted offered a first comprehensive view of the study of the COVID-19 pandemic in the management field. The breadth of the topic dealt with and its implication and/or diffusion in numerous fields of study of the managerial disciplines certainly emerge clearly. At the same time, the in-depth study and analysis conducted on the papers make it possible to appreciate the possible connections and joint ideas for think about the topics analyzed. Tourism and innovation seem to have attracted considerable interest from scholars. Innovation in particular, in a broad and comprehensive vision of managerial studies, offers numerous points of view and common guidelines.

The pandemic has imposed numerous challenges and created new business scenarios and management dynamics, in this context, innovation with its tools and its numerous application possibilities, provides an important and crucial contribution. The analysis shows how the pandemic pushes companies to innovate and overcome the resistance still present on digitalization. At the same time, it is important to bring this evolution back to an ethical, social, and suitable level for the management of human resources.

The paper provides some theoretical and practical implication. From a theoretical point of view, the analysis conducted makes it possible to organize and have a clear and structured vision of the development of managerial studies in relation to the pandemic. This organic vision can be of support for researchers to understand possible links between analyzed topics and which studies have already been developed in specific managerial contexts. Furthermore, the third research question offers some suggestions regarding the evolution of the studies and possible themes not yet investigated in depth.

From a managerial point of view, research can guide managers in a deeper knowledge and awareness of the effects of the pandemic on business management and on the economic context in which it operates. The deepening of the topics in the different facets under analysis and the links between some of these can provide a more organic and systemic vision of the new managerial context in which businesses operate. The overall vision of the various researches shows at current and future entrepreneurs how to orient themselves in order to compete in the new global context, both today and in the post-pandemic, turning activities towards innovation and a new ethical and social vision of business. As it is possible to conclude from the results that emerged, the topic is very young, and this current year and the further developments of the pandemic will contribute to providing important future developments for managerial research. Taking into consideration the analyzed papers, it emerges that some contaminations and joint developments of topic are present, but an important step in the research could be to work on the evaluation of 
suitable business models that can combine the various aspects addressed and emerged from the numerous papers analyzed. Indeed, one of the most evident gaps that emerged is the lack of initial considerations on a possible business model that can cope with the changes of the last year. Finally, it is also important to underline the limitations of this research. The main limitations can be traced back to the methodology used, in particular to the choice of keywords and the selection of a single database (albeit the most widely used and extensive one) which could, in future studies, be further refined.

Author Contributions: Introduction, P.M.; Material and Methods, M.P.; Results, M.P.; Discussion, M.P.; Conclusions, C.S. All authors have read and agreed to the published version of the manuscript.

Funding: This research received no external funding.

Institutional Review Board Statement: Not applicable.

Informed Consent Statement: Not applicable.

Data Availability Statement: Not applicable.

Conflicts of Interest: The authors declare no conflict of interest.

\section{Appendix A}

Table A1. Journals.

\begin{tabular}{|c|c|c|}
\hline Journal & No. & $\%$ \\
\hline IEEE Engineering Management Review & 15 & $9.4 \%$ \\
\hline International Journal of Hospitality Management & 14 & $8.8 \%$ \\
\hline Journal of Business Research & 10 & $6.3 \%$ \\
\hline International Journal of Contemporary Hospitality Management & 5 & $3.1 \%$ \\
\hline Management and Marketing & 5 & $3.1 \%$ \\
\hline Annals of Tourism Research & 4 & $2.5 \%$ \\
\hline British Journal of Management & 4 & $2.5 \%$ \\
\hline Entrepreneurship and Sustainability Issues & 4 & $2.5 \%$ \\
\hline Industrial Marketing Management & 4 & $2.5 \%$ \\
\hline Journal of Asian Finance, Economics and Business & 4 & $2.5 \%$ \\
\hline Journal of Cleaner Production & 4 & $2.5 \%$ \\
\hline Journal of Industrial and Business Economics & 4 & $2.5 \%$ \\
\hline Journal of Service Management & 4 & $2.5 \%$ \\
\hline International Journal of Operations and Production Management & 3 & $1.9 \%$ \\
\hline Academic Journal of Interdisciplinary Studies & 2 & $1.3 \%$ \\
\hline Advances in Science, Technology and Engineering Systems & 2 & $1.3 \%$ \\
\hline Frontiers of Business Research in China & 2 & $1.3 \%$ \\
\hline Global Business and Organizational Excellence & 2 & $1.3 \%$ \\
\hline Human Resource Development International & 2 & $1.3 \%$ \\
\hline International Small Business Journal: Researching Entrepreneurship & 2 & $1.3 \%$ \\
\hline Journal of Air Transport Management & 2 & $1.3 \%$ \\
\hline Journal of Management & 2 & $1.3 \%$ \\
\hline Journal of Retailing and Consumer Services & 2 & $1.3 \%$ \\
\hline Management Research & 2 & $1.3 \%$ \\
\hline Technological Forecasting and Social Change & 2 & $1.3 \%$ \\
\hline Tourism Geographies & 2 & $1.3 \%$ \\
\hline Tourism Management & 2 & $1.3 \%$ \\
\hline Academy of Strategic Management Journal & 1 & $0.6 \%$ \\
\hline American Review of Public Administration & 1 & $0.6 \%$ \\
\hline Asian Business and Management & 1 & $0.6 \%$ \\
\hline Business Economics & 1 & $0.6 \%$ \\
\hline Cities & 1 & $0.6 \%$ \\
\hline Cogent Business and Management & 1 & $0.6 \%$ \\
\hline Enlightening Tourism & 1 & $0.6 \%$ \\
\hline Foresight and STI Governance & 1 & $0.6 \%$ \\
\hline
\end{tabular}


Table A1. Cont.

\begin{tabular}{|c|c|c|}
\hline Journal & No. & $\%$ \\
\hline Gender, Work and Organization & 1 & $0.6 \%$ \\
\hline GENEVA Risk and Insurance Review & 1 & $0.6 \%$ \\
\hline Human Systems Management & 1 & $0.6 \%$ \\
\hline Humanities and Social Sciences Communications & 1 & $0.6 \%$ \\
\hline Indian Journal of Marketing & 1 & $0.6 \%$ \\
\hline International Journal of Entrepreneurship & 1 & $0.6 \%$ \\
\hline International Journal of Integrated Supply Management & 1 & $0.6 \%$ \\
\hline International Journal of Market Research & 1 & $0.6 \%$ \\
\hline International Journal of Supply Chain Management & 1 & $0.6 \%$ \\
\hline $\begin{array}{c}\text { International Journal of Technological Learning, Innovation and } \\
\text { Development }\end{array}$ & 1 & $0.6 \%$ \\
\hline International Journal of Technology & 1 & $0.6 \%$ \\
\hline International Journal of Tourism Cities & 1 & $0.6 \%$ \\
\hline Journal of Accounting and Organizational Change & 1 & $0.6 \%$ \\
\hline Journal of Business Venturing Insights & 1 & $0.6 \%$ \\
\hline Journal of Competitiveness & 1 & $0.6 \%$ \\
\hline Journal of Contingencies and Crisis Management & 1 & $0.6 \%$ \\
\hline Journal of Economics and Management Strategy & 1 & $0.6 \%$ \\
\hline Journal of International Consumer Marketing & 1 & $0.6 \%$ \\
\hline Journal of International Logistics and Trade & 1 & $0.6 \%$ \\
\hline Journal of Outdoor Recreation and Tourism & 1 & $0.6 \%$ \\
\hline Journal of Risk Research & 1 & $0.6 \%$ \\
\hline Journal of Service Research & 1 & $0.6 \%$ \\
\hline Logforum & 1 & $0.6 \%$ \\
\hline International Journal of Entrepreneurial Behaviour and Research & 1 & $0.6 \%$ \\
\hline Organizacija & 1 & $0.6 \%$ \\
\hline Problems and Perspectives in Management & 1 & $0.6 \%$ \\
\hline Public Administration Review & 1 & $0.6 \%$ \\
\hline Publishing Research Quarterly & 1 & $0.6 \%$ \\
\hline Research in International Business and Finance & 1 & $0.6 \%$ \\
\hline Research in Transportation Business and Management & 1 & $0.6 \%$ \\
\hline Research in World Economy & 1 & $0.6 \%$ \\
\hline Research Technology Management & 1 & $0.6 \%$ \\
\hline Social Marketing Quarterly & 1 & $0.6 \%$ \\
\hline Studies in Business and Economics & 1 & $0.6 \%$ \\
\hline Technology in Society & 1 & $0.6 \%$ \\
\hline TEM Journal & 1 & $0.6 \%$ \\
\hline Tourism Management Perspectives & 1 & $0.6 \%$ \\
\hline Uncertain Supply Chain Management & 1 & $0.6 \%$ \\
\hline Work, Aging and Retirement & 1 & $0.6 \%$ \\
\hline $\begin{array}{c}\text { World Journal of Entrepreneurship, Management and Sustainable } \\
\text { Development }\end{array}$ & 1 & $0.6 \%$ \\
\hline WSEAS Transactions on Business and Economics & 1 & $0.6 \%$ \\
\hline Total & 159 & $100 \%$ \\
\hline
\end{tabular}

Table A2. Keyword occurrences and Link Strength.

\begin{tabular}{ccc}
\hline Keyword & Occurrences & Total Link Strength \\
\hline COVID-19 & 91 & 185 \\
Pandemic & 19 & 57 \\
Coronavirus & 17 & 51 \\
Viral Disease & 15 & 73 \\
COVID-19 Pandemic & 12 & 13 \\
Crisis & 10 & 28 \\
Consumer Behaviour & 8 & 18 \\
\hline
\end{tabular}


Table A2. Cont.

\begin{tabular}{|c|c|c|}
\hline Keyword & Occurrences & Total Link Strength \\
\hline Resilience & 8 & 27 \\
\hline Crisis Management & 7 & 24 \\
\hline Management & 7 & 20 \\
\hline Tourism & 7 & 30 \\
\hline Disease Spread & 6 & 28 \\
\hline Engineering & 6 & 15 \\
\hline Epidemic & 6 & 42 \\
\hline Supply Chain Management & 6 & 15 \\
\hline Coronaviruses & 5 & 12 \\
\hline Digital Transformation & 5 & 19 \\
\hline Innovation & 5 & 13 \\
\hline Sustainability & 5 & 12 \\
\hline China & 4 & 14 \\
\hline Dynamic Capabilities & 4 & 7 \\
\hline Managers & 4 & 10 \\
\hline Respiratory Disease & 4 & 27 \\
\hline Social Distancing & 4 & 7 \\
\hline Supply Chains & 4 & 16 \\
\hline Sustainable Development & 4 & 7 \\
\hline Technology & 4 & 11 \\
\hline Tourism Economics & 4 & 25 \\
\hline Tourism Management & 4 & 21 \\
\hline Air Transportation & 3 & 16 \\
\hline Artificial Intelligence & 3 & 15 \\
\hline Consumption Behaviour & 3 & 11 \\
\hline Coronavirus (COVID-19) & 3 & 7 \\
\hline Corporate Social Responsibility & 3 & 4 \\
\hline Digitalization & 3 & 10 \\
\hline Economic Impact & 3 & 16 \\
\hline Employment & 3 & 10 \\
\hline Entrepreneurship & 3 & 4 \\
\hline Global Supply Chain & 3 & 9 \\
\hline Global Value Chains & 3 & 6 \\
\hline Leadership & 3 & 7 \\
\hline Lockdown & 3 & 4 \\
\hline Marketing & 3 & 4 \\
\hline SMEs & 3 & 5 \\
\hline Strategic Approach & 3 & 16 \\
\hline Supply Chain & 3 & 11 \\
\hline Supply Chain Risk & 3 & 6 \\
\hline Tourist Behaviour & 3 & 15 \\
\hline Travel Behaviour & 3 & 21 \\
\hline
\end{tabular}

\section{References}

1. Roubini, N. Coronavirus pandemic has delivered the fastest, deepest economic shock in history. The Guardian, 25 March 2020.

2. Donthu, N.; Gustafsson, A. Effects of COVID-19 on business and research. J. Bus. Res. 2020, 117, 284-289. [CrossRef] [PubMed]

3. Painter, M.; Qiu, T. Political Beliefs affect Compliance with COVID-19 Social Distancing Orders. SSRN Electron. J. 2020. [CrossRef]

4. Koren, M.; Pető, R. Business disruptions from social distancing. PLoS ONE 2020, 15, e0239113. [CrossRef]

5. Ozili, P.; Arun, T. Spillover of COVID-19: Impact on the Global Economy; University Library of Munich: Munich, Germany, 2020.

6. Gössling, S.; Scott, D.; Hall, C.M. Pandemics, tourism and global change: A rapid assessment of COVID-19. J. Sustain. Tour. 2020, 29, 1-20. [CrossRef]

7. Gray, R.S. Agriculture, transportation, and the COVID-19 crisis. Can. J. Agric. Econ. Can. d'agroeconomie 2020, 68, 239-243. [CrossRef]

8. Ratten, V. Coronavirus disease (COVID-19) and sport entrepreneurship. Int. J. Entrep. Behav. Res. 2020, 26, 1379-1388. [CrossRef]

9. Hang, H.; Aroean, L.; Chen, Z. Building emotional attachment during COVID-19. Ann. Tour. Res. 2020, 83, 103006. [CrossRef] [PubMed] 
10. Yuen, K.F.; Wang, X.; Ma, F.; Li, K.X. The Psychological Causes of Panic Buying Following a Health Crisis. Int. J. Environ. Res. Public Health 2020, 17, 3513. [CrossRef] [PubMed]

11. Gao, X.; Shi, X.; Guo, H.; Liu, Y. To buy or not buy food online: The impact of the COVID-19 epidemic on the adoption of e-commerce in China. PLoS ONE 2020, 15, e0237900. [CrossRef]

12. Ting, D.S.W.; Carin, L.; Dzau, V.; Wong, T.Y. Digital technology and COVID-19. Nat. Med. 2020, 26, 459-461. [CrossRef] [PubMed]

13. Woolliscroft, J.O. Innovation in Response to the COVID-19 Pandemic Crisis. Acad. Med. 2020, 95, 1140-1142. [CrossRef] [PubMed]

14. Dhawan, S. Online Learning: A Panacea in the Time of COVID-19 Crisis. J. Educ. Technol. Syst. 2020, 49, 5-22. [CrossRef]

15. Verma, S.; Gustafsson, A. Investigating the emerging COVID-19 research trends in the field of business and management: A bibliometric analysis approach. J. Bus. Res. 2020, 118, 253-261. [CrossRef]

16. Seetharaman, P. Business models shifts: Impact of Covid-19. Int. J. Inf. Manag. 2020, 54, 102173. [CrossRef] [PubMed]

17. Shafi, M.; Liu, J.; Ren, W. Impact of COVID-19 pandemic on micro, small, and medium-sized Enterprises operating in Pakistan. Res. Glob. 2020, 2, 100018. [CrossRef]

18. Vlasschaert, C.; Topf, J.M.; Hiremath, S. Proliferation of Papers and Preprints during the Coronavirus Disease 2019 Pandemic: Progress or Problems with Peer Review? Adv. Chronic Kidney Dis. 2020, 27, 418-426. [CrossRef]

19. García-Villagrán, A.; Cano-Olivos, P.; Martínez-Flores, J.L.; Sánchez-Partida, D. The COVID-19 Effect in Mexican SMEs. Adv. Sci. Technol. Eng. Syst. J. 2020, 5, 63-71. [CrossRef]

20. Merli, R.; Preziosi, M.; Acampora, A. How do scholars approach the circular economy? A systematic literature review. J. Clean. Prod. 2018, 178, 703-722. [CrossRef]

21. Sassanelli, C.; Rosa, P.; Rocca, R.; Terzi, S. Circular economy performance assessment methods: A systematic literature review. J. Clean. Prod. 2019, 229, 440-453. [CrossRef]

22. De Mauro, A.; Greco, M.; Grimaldi, M. A formal definition of Big Data based on its essential features. Libr. Rev. 2016, 65, 122-135. [CrossRef]

23. Hossain, M.M. Current status of global research on novel coronavirus disease (COVID-19): A bibliometric analysis and knowledge mapping. F1000Research 2020, 9, 374. [CrossRef]

24. Dehghanbanadaki, H.; Seif, F.; Vahidi, Y.; Razi, F.; Hashemi, E.; Khoshmirsafa, M.; Aazami, H. Bibliometric analysis of global scientific research on Coronavirus (COVID-19). Med. J. Islam. Repub. Iran 2020, 34, 51.

25. Denyer, D.; Tranfield, D. Producing a systematic review. In The Sage Handbook of Organizational Research Methods; Buchanan, D.A., Bryman, A., Eds.; Sage Publications Ltd.: Thousand Oaks, CA, USA, 2009; pp. 671-689.

26. Kun, Á. Time to Acceptance of 3 Days for Papers about COVID-19. Publcations 2020, 8, 30. [CrossRef]

27. Aveyard, H. Doing a Literature Review in Health and Social Care: A Practical Guide, 3rd ed.; Mc Graw-Hill Education, Ed.; Open University Press: Berkshire, UK, 2014; ISBN 9780335263073.

28. Grant, M.J.; Booth, A. A typology of reviews: An analysis of 14 review types and associated methodologies. Heal. Inf. Libr. J. 2009, 26, 91-108. [CrossRef]

29. Agarwal, A.; Durairajanayagam, D.; Tatagari, S.; Esteves, S.C.; Harlev, A.; Henkel, R.; Roychoudhury, S.; Homa, S.; Puchalt, N.G.; Ramasamy, R.; et al. Bibliometrics: Tracking research impact by selecting the appropriate metrics. Asian J. Androl. 2016, 18, 296-309. [CrossRef] [PubMed]

30. Torraco, R.J. Writing Integrative Literature Reviews: Guidelines and Examples. Hum. Resour. Dev. Rev. 2005, 4, 356-367. [CrossRef]

31. Neely, J.G.; Magit, A.E.; Rich, J.T.; Voelker, C.C.J.; Wang, E.W.; Paniello, R.C.; Nussenbaum, B.; Bradley, J.P. A practical guide to understanding systematic reviews and meta-analyses. Otolaryngol. Neck Surg. 2010, 142, 6-14. [CrossRef] [PubMed]

32. Van Eck, N.J.; Waltman, L. VOS: A New Method for Visualizing Similarities between Objects. In Advances in Data Analysis; Studies in Classification, Data Analysis, and Knowledge Organization; Decker, R., Lenz, H.J., Eds.; Springer: Berlin/Heidelberg, Germany, 2007; pp. 299-306.

33. Waltman, L.; van Eck, N.J. A smart local moving algorithm for large-scale modularity-based community detection. Eur. Phys. J. B 2013, 86, 471. [CrossRef]

34. Wang, Q.; Ngai, E.W. Event study methodology in business research: A bibliometric analysis. Ind. Manag. Data Syst. 2020, 120, 1863-1900. [CrossRef]

35. Su, H.-N.; Lee, P.-C. Mapping knowledge structure by keyword co-occurrence: A first look at journal papers in Technology Foresight. Scientometrics 2010, 85, 65-79. [CrossRef]

36. Merli, R.; Preziosi, M.; Acampora, A.; Lucchetti, M.C.; Petrucci, E. Recycled fibers in reinforced concrete: A systematic literature review. J. Clean. Prod. 2020, 248, 119207. [CrossRef]

37. Mayring, P. Qualitative content analysis. A companion to qualitative research. FORUM Qual. Soc. Res. 2004, 1, 159-176.

38. Polit, D.F.; Beck, C.T. Nursing Research: Principles and Methods; Lippincott Williams \& Wilkins: Philadelphia, PA, USA, 2004.

39. Elo, S.; Kyngäs, H. The qualitative content analysis process. J. Adv. Nurs. 2008, 62, 107-115. [CrossRef]

40. Fotiadis, A.; Polyzos, S.; Huan, T.-C.T. The good, the bad and the ugly on COVID-19 tourism recovery. Ann. Tour. Res. 2021, 87, 103117. [CrossRef]

41. Kaushal, V.; Srivastava, S. Hospitality and tourism industry amid COVID-19 pandemic: Perspectives on challenges and learnings from India. Int. J. Hosp. Manag. 2021, 92, 102707. [CrossRef] [PubMed] 
42. Pan, T.; Shu, F.; Kitterlin-Lynch, M.; Beckman, E. Perceptions of cruise travel during the COVID-19 pandemic: Market recovery strategies for cruise businesses in North America. Tour. Manag. 2021, 85, 104275. [CrossRef]

43. Sobaih, A.E.E.; Elshaer, I.; Hasanein, A.M.; Abdelaziz, A.S. Responses to COVID-19: The role of performance in the relationship between small hospitality enterprises' resilience and sustainable tourism development. Int. J. Hosp. Manag. 2021, $94,102824$. [CrossRef]

44. Zheng, D.; Luo, Q.; Ritchie, B.W. Afraid to travel after COVID-19? Self-protection, coping and resilience against pandemic 'travel fear'. Tour. Manag. 2021, 83, 104261. [CrossRef]

45. Aburumman, A.A. COVID-19 impact and survival strategy in business tourism market: The example of the UAE MICE industry. Humanit. Soc. Sci. Commun. 2020, 7, 1-11. [CrossRef]

46. Budd, L.; Ison, S.; Adrienne, N. European airline response to the COVID-19 pandemic-Contraction, consolidation and future considerations for airline business and management. Res. Transp. Bus. Manag. 2020, 37, 100578. [CrossRef]

47. Dimitrios, B.; Christos, P.; Ioannis, R.; Vasiliadis, L. Strategic Management in the Hotel Industry: Proposed Strategic Practices to Recover from COVID-19 Global Crisis. Acad. J. Interdiscip. Stud. 2020, 9, 130. [CrossRef]

48. Hao, F.; Xiao, Q.; Chon, K. COVID-19 and China's Hotel Industry: Impacts, a Disaster Management Framework, and PostPandemic Agenda. Int. J. Hosp. Manag. 2020, 90, 102636. [CrossRef] [PubMed]

49. Haywood, K.M. A post COVID-19 future-tourism re-imagined and re-enabled. Tour. Geogr. 2020, 22, 599-609. [CrossRef]

50. Jiang, Y.; Wen, J. Effects of COVID-19 on hotel marketing and management: A perspective article. Int. J. Contemp. Hosp. Manag. 2020, 32, 2563-2573. [CrossRef]

51. Jiricka-Pürrer, A.; Brandenburg, C.; Pröbstl-Haider, U. City tourism pre- and post-covid-19 pandemic-Messages to take home for climate change adaptation and mitigation? J. Outdoor Recreat. Tour. 2020, 31, 100329. [CrossRef]

52. Kock, F.; Nørfelt, A.; Josiassen, A.; Assaf, A.G.; Tsionas, M.G. Understanding the COVID-19 tourist psyche: The Evolutionary Tourism Paradigm. Ann. Tour. Res. 2020, 85, 103053. [CrossRef] [PubMed]

53. Koh, E. The end of over-tourism? Opportunities in a post-Covid-19 world. Int. J. Tour. Cities 2020, 6, 1015-1023. [CrossRef]

54. Kukanja, M.; Planinc, T.; Sikošek, M. Crisis Management Practices in Tourism SMEs during the Covid-19 Pandemic. Organizacija 2020, 53, 346-361. [CrossRef]

55. Ocheni, S.I.; Agba, A.M.O.; Agba, M.S.; Eteng, F.O. Covid-19 and the Tourism Industry: Critical Overview, Lessons and Policy Options. Acad. J. Interdiscip. Stud. 2020, 9, 114. [CrossRef]

56. Qiu, R.T.R.; Park, J.; Li, S.; Song, H. Social costs of tourism during the COVID-19 pandemic. Ann. Tour. Res. 2020, 84, 102994. [CrossRef] [PubMed]

57. Sharma, A.; Nicolau, J.L. An open market valuation of the effects of COVID-19 on the travel and tourism industry. Ann. Tour. Res. 2020, 83, 102990. [CrossRef]

58. Sigala, M. Tourism and COVID-19: Impacts and implications for advancing and resetting industry and research. J. Bus. Res. 2020, 117, 312-321. [CrossRef] [PubMed]

59. Uğur, N.G.; Akbıyık, A. Impacts of COVID-19 on global tourism industry: A cross-regional comparison. Tour. Manag. Perspect. 2020, 36, 100744. [CrossRef] [PubMed]

60. Zhang, J.; Xie, C.; Wang, J.; Morrison, A.M.; Coca-Stefaniak, J.A. Responding to a major global crisis: The effects of hotel safety leadership on employee safety behaviour during COVID-19. Int. J. Contemp. Hosp. Manag. 2020, 32, 3365-3389. [CrossRef]

61. Chadee, D.; Ren, S.; Tang, G. Is digital technology the magic bullet for performing work at home? Lessons learned for post COVID-19 recovery in hospitality management. Int. J. Hosp. Manag. 2021, 92, 102718. [CrossRef]

62. Lee, S.M.; Trimi, S. Convergence innovation in the digital age and in the COVID-19 pandemic crisis. J. Bus. Res. 2021, 123, 14-22. [CrossRef]

63. Akinwale, Y.O. Technology innovation and financial performance of MSMEs during Covid-19 lockdown in Dammam area of Saudi Arabia: A case of food and beverage sector. Int. J. Technol. Learn. Innov. Dev. 2020, 12, 136-152. [CrossRef]

64. Almeida, F.; Santos, J.D.; Monteiro, J.A. The Challenges and Opportunities in the Digitalization of Companies in a Post-COVID-19 World. IEEE Eng. Manag. Rev. 2020, 48, 97-103. [CrossRef]

65. Amadi-Echendu, J.; Thopil, G.A. Resilience Is Paramount for Managing Socio-Technological Systems During and Post-Covid-19. IEEE Eng. Manag. Rev. 2020, 48, 118-128. [CrossRef]

66. Barragan-Quintero, R.V.; Barragan-Quintero, F.; Ahumada-Tello, E. The Impact of COVID-19 on Innovation: Old Projections or New Expectations After the Pandemic? IEEE Eng. Manag. Rev. 2020, 48, 197-201. [CrossRef]

67. Bartsch, S.; Weber, E.; Büttgen, M.; Huber, A. Leadership matters in crisis-induced digital transformation: How to lead service employees effectively during the COVID-19 pandemic. J. Serv. Manag. 2020, 32, 71-85. [CrossRef]

68. Chayomchai, A. The Online Technology Acceptance Model of Generation-Z People in Thailand during COVID-19 Crisis. Manag. Mark. 2020, 15, 496-512. [CrossRef]

69. Chesbrough, H. To recover faster from Covid-19, open up: Managerial implications from an open innovation perspective. Ind. Mark. Manag. 2020, 88, 410-413. [CrossRef]

70. El Sayed, E.M.A.M. How AI, data science and technology is used to fight the pandemic COVID-19: Case study in Saudi Arabia environment. Res. World Econ. 2020, 11, 409-419. [CrossRef] 
71. Fernando, E.; Surjandy, S.; Meyliana, M.; Wijadja, H.A.; Hidayat, D.; Kusumaningtyas, A.W.; Heryatno, R. Factors Influencing the Intention to Use Technology Services to Implement Self-Service Technology Case Study: Situation Pandemic Covid-19. Adv. Sci. Technol. Eng. Syst. J. 2020, 5, 342-347. [CrossRef]

72. Heinonen, K.; Strandvik, T. Reframing service innovation: COVID-19 as a catalyst for imposed service innovation. J. Serv. Manag. 2020, 32, 101-112. [CrossRef]

73. Henkel, A.P.; Čaić, M.; Blaurock, M.; Okan, M. Robotic transformative service research: Deploying social robots for consumer well-being during COVID-19 and beyond. J. Serv. Manag. 2020, 31, 1131-1148. [CrossRef]

74. Ilieva, G.; Yankova, T. IoT in Distance Learning during the COVID-19 Pandemic. TEM J. 2020, 9, 1669-1674. [CrossRef]

75. Kalla, A.; Hewa, T.; Mishra, R.A.; Ylianttila, M.; Liyanage, M. The Role of Blockchain to Fight Against COVID-19. IEEE Eng. Manag. Rev. 2020, 48, 85-96. [CrossRef]

76. Ng, J.J.; Navaretnam, S.; Wei, J.L.Q. Considerations for IT Management in a COVID-19 World. IEEE Eng. Manag. Rev. 2020, 48, 16-18. [CrossRef]

77. Razif, M.; Miraja, B.A.; Persada, S.F.; Nadlifatin, R.; Belgiawan, P.F.; Redi, A.A.N.P.; Lin, S.-C. Investigating the role of environmental concern and the unified theory of acceptance and use of technology on working from home technologies adoption during COVID-19. Entrep. Sustain. Issues 2020, 8, 795-808. [CrossRef]

78. Shankar, K. The Impact of COVID-19 on IT Services Industry-Expected Transformations. Br. J. Manag. 2020, 31, 450-452. [CrossRef]

79. Shin, H.; Kang, J. Reducing perceived health risk to attract hotel customers in the COVID-19 pandemic era: Focused on technology innovation for social distancing and cleanliness. Int. J. Hosp. Manag. 2020, 91, 102664. [CrossRef] [PubMed]

80. Zeng, Z.; Chen, P.-J.; Lew, A.A. From high-touch to high-tech: COVID-19 drives robotics adoption. Tour. Geogr. 2020, 22, 724-734. [CrossRef]

81. Agarwal, P. Shattered but smiling: Human resource management and the wellbeing of hotel employees during COVID-19. Int. J. Hosp. Manag. 2021, 93, 102765. [CrossRef]

82. Al-Abrrow, H.; Al-Maatoq, M.; Alharbi, R.K.; Alnoor, A.; Abdullah, H.O.; Abbas, S.; Khattak, Z.Z. Understanding employees' responses to the COVID-19 pandemic: The attractiveness of healthcare jobs. Glob. Bus. Organ. Excel. 2021, 40, 19-33. [CrossRef]

83. Bufquin, D.; Park, J.-Y.; Back, R.M.; de Souza Meira, J.V.; Hight, S.K. Employee work status, mental health, substance use, and career turnover intentions: An examination of restaurant employees during COVID-19. Int. J. Hosp. Manag. 2021, 93, 102764. [CrossRef]

84. Jung, H.S.; Jung, Y.S.; Yoon, H.H. COVID-19: The effects of job insecurity on the job engagement and turnover intent of deluxe hotel employees and the moderating role of generational characteristics. Int. J. Hosp. Manag. 2021, 92, 102703. [CrossRef]

85. Stergiou, D.P.; Farmaki, A. Ability and willingness to work during COVID-19 pandemic:Perspectives of front-line hotel employees. Int. J. Hosp. Manag. 2021, 93, 102770. [CrossRef]

86. Siddiqui, T.A.; Ahmed, H.; Naushad, M. Diffusion of COVID-19 impact across selected stock markets: A wavelet coherency analysis. Investig. Manag. Financ. Innov. 2020, 17, 202-214. [CrossRef]

87. Ahmed, T.; Khan, M.S.; Thitivesa, D.; Siraphatthada, Y.; Phumdara, T. Impact of employees engagement and knowledge sharing on organizational performance: Study of HR challenges in COVID-19 pandemic. Hum. Syst. Manag. 2020, 39, 589-601. [CrossRef]

88. Alam, M. Organisational processes and COVID-19 pandemic: Implications for job design. J. Account. Organ. Chang. 2020, 16, 599-606. [CrossRef]

89. Bolisani, E.; Scarso, E.; Ipsen, C.; Kirchner, K.; Hansen, J.P. Working from home during COVID-19 pandemic: Lessons learned and issues. Manag. Mark. 2020, 15, 458-476. [CrossRef]

90. Carnevale, J.B.; Hatak, I. Employee adjustment and well-being in the era of COVID-19: Implications for human resource management. J. Bus. Res. 2020, 116, 183-187. [CrossRef]

91. Clancy, A. On mothering and being mothered: A personal reflection on women's productivity during COVID-19. Gender Work Organ. 2020, 27, 857-859. [CrossRef]

92. Cohen, G.D. Measuring employment during COVID-19: Challenges and opportunities. Bus. Econ. 2020, 55, 229-239. [CrossRef]

93. Fana, M.; Pérez, S.T.; Fernández-Macías, E. Employment impact of Covid-19 crisis: From short term effects to long terms prospects. J. Ind. Bus. Econ. 2020, 47, 1-20. [CrossRef]

94. Kooij, D.T.A.M. The Impact of the Covid-19 Pandemic on Older Workers: The Role of Self-Regulation and Organizations. Work. Aging Retire. 2020, 6, 233-237. [CrossRef]

95. Lee, D.M.M. Covid-19: Agnotology, inequality, and leadership. Hum. Resour. Dev. Int. 2020, 23, 333-346. [CrossRef]

96. Muttaqin, G.F.; Taqi, M.; Arifin, B. Job Performance During COVID-19 Pandemic: A Study on Indonesian Startup Companies. J. Asian Financ. Econ. Bus. 2020, 7, 1027-1033. [CrossRef]

97. Wolor, C.W.; Solikhah, S.; Fidhyallah, N.F.; Lestari, D.P. Effectiveness of E-Training, E-Leadership, and Work Life Balance on Employee Performance during COVID-19. J. Asian Financ. Econ. Bus. 2020, 7, 443-450. [CrossRef]

98. Yawson, R. Strategic flexibility analysis of HRD research and practice post COVID-19 pandemic. Hum. Resour. Dev. Int. 2020, 23, 406-417. [CrossRef]

99. Kim, S.; Kim, P.B.; Lee, G. Predicting hospitality employees' safety performance behaviours in the COVID-19 pandemic. Int. J. Hosp. Manag. 2021, 93, 102797. [CrossRef] 
100. Linden, E. Pandemics and environmental shocks: What aviation managers should learn from COVID-19 for long-term planning. J. Air Transp. Manag. 2021, 90, 101944. [CrossRef] [PubMed]

101. Albers, S.; Rundshagen, V. European airlines' strategic responses to the COVID-19 pandemic (January-May, 2020). J. Air Transp. Manag. 2020, 87, 101863. [CrossRef] [PubMed]

102. Chaves-Maza, M.; Martel, E.M.F. Entrepreneurship support ways after the COVID-19 crisis. Entrep. Sustain. Issues 2020, 8 , 662-681. [CrossRef]

103. Dobrowolski, Z. After COVID-19. Reorientation of crisis management in crisis. Entrep. Sustain. Issues 2020, 8, 799-810. [CrossRef]

104. Fathurahman, H.; Berawi, M.A.; Sulistyarini, I.; Kusuma, A.; Nasution, Y.; Komarudin. Post COVID-19 Recovery Models and Strategies for Aviation in Indonesia. Int. J. Technol. 2020, 11, 1265-1274. [CrossRef]

105. Foss, N.J. Behavioural Strategy and the COVID-19 Disruption. J. Manag. 2020, 46, 1322-1329.

106. Kashyap, A.; Raghuvanshi, J. A preliminary study on exploring the critical success factors for developing COVID-19 preventive strategy with an economy centric approach. Manag. Res. 2020, 18, 357-377. [CrossRef]

107. Kristinae, V.; Wardana, I.M.; Giantari, I.G.A.K.; Rahyuda, A.G. The role of powerful business strategy on value innovation capabilities to improve marketing performance during the COVID-19 pandemic. Uncertain Supply Chain Manag. 2020, 8, 675-684. [CrossRef]

108. Lai, I.K.W.; Wong, J.W.C. Comparing crisis management practices in the hotel industry between initial and pandemic stages of COVID-19. Int. J. Contemp. Hosp. Manag. 2020, 32, 3135-3156. [CrossRef]

109. Wen, J.; Wang, W.; Kozak, M.; Liu, X.; Hou, H. Many brains are better than one: The importance of interdisciplinary studies on COVID-19 in and beyond tourism. Tour. Recreat. Res. 2020, 1-4. [CrossRef]

110. Liu, N.; Chen, Z.; Bao, G. Role of media coverage in mitigating COVID-19 transmission: Evidence from China. Technol. Forecast. Soc. Chang. 2021, 163, 120435. [CrossRef] [PubMed]

111. Manolova, T.S.; Brush, C.G.; Edelman, L.F.; Elam, A. Pivoting to stay the course: How women entrepreneurs take advantage of opportunities created by the COVID-19 pandemic. Int. Small Bus. J. Res. Entrep. 2020, 38, 481-491. [CrossRef]

112. Rejeb, A.; Rejeb, K.; Keogh, J.G. Covid-19 and the food chain? Impacts and future research trends. Logforum 2020, $16,475-485$.

113. Song, K.; Jiao, S.; Zhu, Q.; Wu, H. A Proactive and Practical COVID-19 Testing Strategy. IEEE Eng. Manag. Rev. 2020, 48, 63-71. [CrossRef]

114. Trachsler, T.; Jong, W. Crisis management in times of COVID-19: Game, set or match? J. Contingencies Crisis Manag. 2020, 28, 485-486. [CrossRef]

115. Yang, K. Unprecedented Challenges, Familiar Paradoxes: COVID-19 and Governance in a New Normal State of Risks. Public Adm. Rev. 2020, 80, 657-664. [CrossRef]

116. Byrd, K.; Her, E.; Fan, A.; Almanza, B.; Liu, Y.; Leitch, S. Restaurants and COVID-19: What are consumers' risk perceptions about restaurant food and its packaging during the pandemic? Int. J. Hosp. Manag. 2021, 94, 102821. [CrossRef]

117. Naeem, M. Do social media platforms develop consumer panic buying during the fear of Covid-19 pandemic. J. Retail. Consum. Serv. 2021, 58, 102226. [CrossRef]

118. Yu, J.; Lee, K.; Hyun, S.S. Understanding the influence of the perceived risk of the coronavirus disease (COVID-19) on the post-traumatic stress disorder and revisit intention of hotel guests. J. Hosp. Tour. Manag. 2021, 46, 327-335. [CrossRef]

119. Zwanka, R.J.; Buff, C. COVID-19 Generation: A Conceptual Framework of the Consumer Behavioural Shifts to Be Caused by the COVID-19 Pandemic. J. Int. Consum. Mark. 2021, 33, 58-67. [CrossRef]

120. Ahmed, R.R.; Streimikiene, D.; Rolle, J.-A.; Duc, P.A. The COVID-19 pandemic and the antecedants for the impulse buying behaviour of US citizens. J. Compet. 2020, 12, 5-27.

121. Alshaketheep, K.M.K.I.; Salah, A.A.; Alomari, K.M.; Khaled, A.S.D.; Abu Jray, A.A. Digital Marketing during COVID 19: Consumer's Perspective. WSEAS Trans. Bus. Econ. 2020, 17, 831-841. [CrossRef]

122. Bond, E.U., III; De Jong, A.; Eggert, A.; Houston, M.B.; Kleinaltenkamp, M.; Kohli, A.K.; Ritter, T.; Ulaga, W. The Future of B2B Customer Solutions in a Post-COVID-19 Economy: Managerial Issues and an Agenda for Academic Inquiry. J. Serv. Res. 2020, 23, 401-408. [CrossRef]

123. Karpen, I.O.; Conduit, J. Engaging in times of COVID-19 and beyond: Theorizing customer engagement through different paradigmatic lenses. J. Serv. Manag. 2020, 31, 1163-1174. [CrossRef]

124. Abdullah, W.J.; Kim, S. Singapore's Responses to the COVID-19 Outbreak: A Critical Assessment. Am. Rev. Public Adm. 2020, 50, 770-776. [CrossRef]

125. Kirk, C.P.; Rifkin, L.S. I'll trade you diamonds for toilet paper: Consumer reacting, coping and adapting behaviours in the COVID-19 pandemic. J. Bus. Res. 2020, 117, 124-131. [CrossRef]

126. Oana, D. The Impact of the Current Crisis Generated by the COVID-19 Pandemic on Consumer Behaviour. Stud. Bus. Econ. 2020, 15, 85-99. [CrossRef]

127. Pham, V.K.; Thi, T.H.D.; Le, T.H.H. A study on the COVID-19 awareness affecting the consumer perceived benefits of online shopping in Vietnam. Cogent Bus. Manag. 2020, 7, 7. [CrossRef]

128. Prentice, C.; Chen, J.; Stantic, B. Timed intervention in COVID-19 and panic buying. J. Retail. Consum. Serv. 2020, 57, 102203. [CrossRef]

129. Sheth, J. Impact of Covid-19 on consumer behaviour: Will the old habits return or die? J. Bus. Res. 2020, 117, 280-283. [CrossRef] [PubMed] 
130. Wang, Y.; Xu, R.; Schwartz, M.; Ghosh, D.; Chen, X. COVID-19 and Retail Grocery Management: Insights from a Broad-Based Consumer Survey. IEEE Eng. Manag. Rev. 2020, 48, 202-211. [CrossRef]

131. Ketchen, D.J., Jr.; Craighead, C.W. Research at the Intersection of Entrepreneurship, Supply Chain Management, and Strategic Management: Opportunities Highlighted by COVID-19. J. Manag. 2020, 46, 1330-1341. [CrossRef]

132. Fonseca, L.M.; Azevedo, A.L. COVID-19: Outcomes for Global Supply Chains. Manag. Mark. 2020, 15, 424-438. [CrossRef]

133. Kwon, O.K. How is the COVID-19 Pandemic Affecting Global Supply Chains, Logistics, and Transportation? J. Int. Logist. Trade 2020, 18, 107-111. [CrossRef]

134. Sharma, A.; Adhikary, A.; Borah, S.B. Covid-19's impact on supply chain decisions: Strategic insights from NASDAQ 100 firms using Twitter data. J. Bus. Res. 2020, 117, 443-449. [CrossRef]

135. Derevyankina, E.S.; Yankovskaya, D.G. The impact of Covid-19 on supply chain management and global economy development. Int. J. Supply Chain Manag. 2020, 9, 765-774.

136. Gunessee, S.; Subramanian, N. Ambiguity and its coping mechanisms in supply chains lessons from the Covid-19 pandemic and natural disasters. Int. J. Oper. Prod. Manag. 2020, 40, 1201-1223. [CrossRef]

137. Veselovská, L. Supply chain disruptions in the context of early stages of the global COVID-19 outbreak. Probl. Perspect. Manag. 2020, 18, 490-500. [CrossRef]

138. Xu, Z.; Elomri, A.; Kerbache, L.; El Omri, A. Impacts of COVID-19 on Global Supply Chains: Facts and Perspectives. IEEE Eng. Manag. Rev. 2020, 48, 153-166. [CrossRef]

139. Ishida, S. Perspectives on Supply Chain Management in a Pandemic and the Post-COVID-19 Era. IEEE Eng. Manag. Rev. 2020, 48, 146-152. [CrossRef]

140. Quayson, M.; Bai, C.; Osei, V. Digital Inclusion for Resilient Post-COVID-19 Supply Chains: Smallholder Farmer Perspectives. IEEE Eng. Manag. Rev. 2020, 48, 104-110. [CrossRef]

141. Remko, V.H. Research opportunities for a more resilient post-COVID-19 supply chain-Closing the gap between research findings and industry practice. Int. J. Oper. Prod. Manag. 2020, 40, 341-355. [CrossRef]

142. Al-Mansour, J.F.; Al-Ajmi, S.A. Coronavirus 'COVID-19'-Supply chain disruption and implications for strategy, economy, and management. J. Asian Financ. Econ. Bus. 2020, 7, 659-672. [CrossRef]

143. Ivanov, D.; Das, A. Coronavirus (COVID-19/SARS-CoV-2) and supply chain resilience: A research note. Int. J. Integr. Supply Manag. 2020, 13, 90-102. [CrossRef]

144. Trautrims, A.; Schleper, M.C.; Cakir, M.S.; Gold, S. Survival at the expense of the weakest? Managing modern slavery risks in supply chains during COVID-19. J. Risk Res. 2020, 23, 1067-1072. [CrossRef]

145. Al-Fadly, A. Impact of COVID-19 on SMEs and employment. Entrep. Sustain. Issues 2020, 8, 629-648. [CrossRef]

146. Amuda, Y.J. Impact of coronavirus on small and medium enterprises (SMES): Towards post-COVID-19 economic recovery in Nigeria. Acad. Strateg. Manag. J. 2020, 19, 1-11.

147. Cowling, M.; Brown, R.; Rocha, A. Did you save some cash for a rainy COVID-19 day? The crisis and SMEs. Int. Small Bus. J. Res. Entrep. 2020, 38, 593-604. [CrossRef]

148. Effendi, M.I.; Sugandini, D.; Istanto, Y. Social Media Adoption in SMEs Impacted by COVID-19: The TOE Model. J. Asian Financ. Econ. Bus. 2020, 7, 915-925. [CrossRef]

149. Fairlie, R. The impact of COVID-19 on small business owners: Evidence from the first three months after widespread socialdistancing restrictions. J. Econ. Manag. Strategy 2020, 29, 727-740. [CrossRef]

150. Guo, H.; Yang, Z.; Huang, R.; Guo, A. The digitalization and public crisis responses of small and medium enterprises: Implications from a COVID-19 survey. Front. Bus. Res. China 2020, 14, 1-25. [CrossRef]

151. Juergensen, J.; Guimón, J.; Narula, R. European SMEs amidst the COVID-19 crisis: Assessing impact and policy responses. J. Ind. Bus. Econ. 2020, 47, 499-510. [CrossRef]

152. Kraus, S.; Clauss, T.; Breier, M.; Gast, J.; Zardini, A.; Tiberius, V. The economics of COVID-19: Initial empirical evidence on how family firms in five European countries cope with the corona crisis. Int. J. Entrep. Behav. Res. 2020, 26, 1067-1092. [CrossRef]

153. Kuckertz, A.; Brändle, L.; Gaudig, A.; Hinderer, S.; Morales Reyes, C.A.; Prochotta, A.; Steinbrink, K.M.; Berger, E.S.C. Startups in times of crisis-A rapid response to the COVID-19 pandemic. J. Bus. Ventur. Insights 2020, 13, e00169. [CrossRef]

154. Punescu, C.; Mátyus, E. Resilience measures to dealing with the COVID-19 pandemic Evidence from Romanian micro and small enterprises. Manag. Mark. 2020, 15, 439-457.

155. Resmi, S.; Pahlevi, R.W.; Sayekti, F. The growth of creative micro, small, and medium enterprises (MSMES) business in special region of yogyakarta before and after covid-19 pandemic. Int. J. Entrep. 2020, 24, 1-8.

156. Cankurtaran, P.; Beverland, M.B. Using design thinking to respond to crises: B2B lessons from the 2020 COVID-19 pandemic. Ind. Mark. Manag. 2020, 88, 255-260. [CrossRef]

157. Crick, J.M.; Crick, D. Coopetition and COVID-19: Collaborative business-to-business marketing strategies in a pandemic crisis. Ind. Mark. Manag. 2020, 88, 206-213. [CrossRef]

158. Lee, N.R. Reducing the Spread of COVID-19: A Social Marketing Perspective. Soc. Mark. Q. 2020, 26, 259-265. [CrossRef]

159. Maulana, N. Research Trends in Marketing Science before COVID-19 Outbreak: A Literature Review. Manag. Mark. 2020, 15, 514-533. [CrossRef]

160. Nguyen, H.V.; Tran, H.X.; Van Huy, L.; Nguyen, X.N.; Do, M.T.; Nguyen, N. Online Book Shopping in Vietnam: The Impact of the COVID-19 Pandemic Situation. Publ. Res. Q. 2020, 36, 437-445. [CrossRef] 
161. Pantano, E.; Pizzi, G.; Scarpi, D.; Dennis, C. Competing during a pandemic? Retailers' ups and downs during the COVID-19 outbreak. J. Bus. Res. 2020, 116, 209-213. [CrossRef]

162. Pillania, R.K. COVID-19: A Huge Opportunity for Innovation in Marketing. Indian J. Mark. 2020, 50, 80-87. [CrossRef]

163. Tavares, F.; Santos, E.; Diogo, A.; Ratten, V. An analysis of the experiences based on experimental marketing: Pandemic COVID-19 quarantine. World J. Entrep. Manag. Sustain. Dev. 2020, 16, 327-340. [CrossRef]

164. Wang, Y.; Hong, A.; Li, X.; Gao, J. Marketing innovations during a global crisis: A study of China firms' response to COVID-19. J. Bus. Res. 2020, 116, 214-220. [CrossRef]

165. Webber, R. COVID-19 and race: Protecting data or saving lives? Int. J. Mark. Res. 2020, 62, 528-537. [CrossRef]

166. Guida, C.; Carpentieri, G. Quality of life in the urban environment and primary health services for the elderly during the Covid-19 pandemic: An application to the city of Milan (Italy). Cities 2021, 110, 103038. [CrossRef]

167. Jiang, P.; Fu, X.; Van Fan, Y.; Klemeš, J.J.; Chen, P.; Ma, S.; Zhang, W. Spatial-temporal potential exposure risk analytics and urban sustainability impacts related to COVID-19 mitigation: A perspective from car mobility behaviour. J. Clean. Prod. 2021, 279, 123673. [CrossRef]

168. Thakur, V. Framework for PESTEL dimensions of sustainable healthcare waste management: Learnings from COVID-19 outbreak. J. Clean. Prod. 2021, 287, 125562. [CrossRef]

169. Amankwah-Amoah, J. Stepping up and stepping out of COVID-19: New challenges for environmental sustainability policies in the global airline industry. J. Clean. Prod. 2020, 271, 123000. [CrossRef]

170. Dewick, P.; Pineda, J.; Ramlogan, R. Hand in Glove? Processes of Formalization and the Circular Economy Post-COVID-19. IEEE Eng. Manag. Rev. 2020, 48, 176-183. [CrossRef]

171. Jones, P.; Comfort, D. The COVID-19 crisis and sustainability in the hospitality industry. Int. J. Contemp. Hosp. Manag. 2020, 32, 3037-3050. [CrossRef]

172. Sarkis, J. Supply chain sustainability: Learning from the COVID-19 pandemic. Int. J. Oper. Prod. Manag. 2020, 41, 63-73. [CrossRef]

173. Vasiev, M.; Bi, K.; Denisov, A.; Bocharnikov, V. How COVID-19 Pandemics Influences Chinese Economic Sustainability. Foresight STI Gov. 2020, 14, 7-22. [CrossRef]

174. Popkova, E.; DeLo, P.; Sergi, B.S. Corporate Social Responsibility Amid Social Distancing During the COVID-19 Crisis: BRICS vs. OECD Countries. Res. Int. Bus. Financ. 2021, 55, 101315. [CrossRef]

175. Qiu, S.; Jiang, J.; Liu, X.; Chen, M.-H.; Yuan, X. Can corporate social responsibility protect firm value during the COVID-19 pandemic? Int. J. Hosp. Manag. 2021, 93, 102759. [CrossRef]

176. Aguinis, H.; Villamor, I.; Gabriel, K.P. Understanding employee responses to COVID-19: A behavioural corporate social responsibility perspective. Manag. Res. 2020, 18, 421-438. [CrossRef]

177. He, H.; Harris, L. The impact of Covid-19 pandemic on corporate social responsibility and marketing philosophy. J. Bus. Res. 2020, 116, 176-182. [CrossRef] [PubMed]

178. Huang, H.; Liu, S.Q. “Donate to help combat COVID-19!” How typeface affects the effectiveness of CSR marketing? Int. J. Contemp. Hosp. Manag. 2020, 32, 3315-3333. [CrossRef]

179. Liu, F.; Meng, L.; Zhao, Y.; Duan, S. The influence of the corporate social responsibility disclosures on consumer brand attitudes under the impact of COVID-19. Front. Bus. Res. China 2020, 14, 28. [CrossRef]

180. Aslam, F.; Aziz, S.; Nguyen, D.K.; Mughal, K.S.; Khan, M. On the efficiency of foreign exchange markets in times of the COVID-19 pandemic. Technol. Forecast. Soc. Chang. 2020, 161, 120261. [CrossRef]

181. Bretas, V.P.G.; Alon, I. The impact of COVID-19 on franchising in emerging markets: An example from Brazil. Glob. Bus. Organ. Excell. 2020, 39, 6-16. [CrossRef]

182. Guimón, J.; Narula, R. Ending the COVID-19 Pandemic Requires More International Collaboration. Res. Technol. Manag. 2020, 63, 38-41. [CrossRef]

183. Leone, D.; Panetti, E.; Caporuscio, A.; Pietronudo, M.C. Changes in the Market Access Process to Combat COVID-19. An Exploratory Study in Italy. IEEE Eng. Manag. Rev. 2020, 48, 184-196. [CrossRef]

184. Strange, R. The 2020 Covid-19 pandemic and global value chains. J. Ind. Bus. Econ. 2020, 47, 455-465. [CrossRef]

185. Verbeke, A. Will the COVID-19 Pandemic Really Change the Governance of Global Value Chains? Br. J. Manag. 2020, 31, 444-446. [CrossRef]

186. Hossain, M. The effect of the Covid-19 on sharing economy activities. J. Clean. Prod. 2021, 280, 124782. [CrossRef]

187. Song, H.J.; Yeon, J.; Lee, S. Impact of the COVID-19 pandemic: Evidence from the U.S. restaurant industry. Int. J. Hosp. Manag. 2021, 92, 102702. [CrossRef]

188. Kour, P.; Jasrotia, A.; Gupta, S. Understanding the impact of airport service quality on passengers' revisit intentions amidst COVID-19 pandemic. Enl. Tour. 2020, 10, 358-386. [CrossRef]

189. Richter, A.; Wilson, T.C. Covid-19: Implications for insurer risk management and the insurability of pandemic risk. Geneva Risk Insur. Rev. 2020, 45, 171-199. [CrossRef]

190. Robles, M.A.G. Organizational Transformation during COVID-19. IEEE Eng. Manag. Rev. 2020, 48, 31-36. [CrossRef]

191. Giammetti, R.; Papi, L.; Teobaldelli, D.; Ticchi, D. The Italian value chain in the pandemic: The input-output impact of Covid-19 lockdown. J. Ind. Bus. Econ. 2020, 47, 483-497. [CrossRef] 
192. Okorie, O.S.; Subramoniam, R.; Charnley, F.; Patsavellas, J.; Widdifield, D.; Salonitis, K. Manufacturing in the Time of COVID-19: An Assessment of Barriers and Enablers. IEEE Eng. Manag. Rev. 2020, 48, 167-175. [CrossRef]

193. Rapaccini, M.; Saccani, N.; Kowalkowski, C.; Paiola, M.; Adrodegari, F. Navigating disruptive crises through service-led growth: The impact of COVID-19 on Italian manufacturing firms. Ind. Mark. Manag. 2020, 88, 225-237. [CrossRef]

194. Steen, T.; Brandsen, T. Coproduction during and after the COVID-19 Pandemic: Will It Last? Public Adm. Rev. 2020, 80, 851-855. [CrossRef] [PubMed]

195. Budhwar, P.; Cumming, D. New Directions in Management Research and Communication: Lessons from the COVID-19 Pandemic. Br. J. Manag. 2020, 31, 441-443. [CrossRef]

196. Islam, A.N.; Laato, S.; Talukder, S.; Sutinen, E. Misinformation sharing and social media fatigue during COVID-19: An affordance and cognitive load perspective. Technol. Forecast. Soc. Chang. 2020, 159, 120201. [CrossRef] [PubMed]

197. Arias Velásquez, R.M.; Mejía Lara, J.V. Knowledge management in two universities before and during the COVID-19 effect in Peru. Technol. Soc. 2021, 64, 101479. [CrossRef]

198. Beech, N.; Anseel, F. COVID-19 and Its Impact on Management Research and Education: Threats, Opportunities and a Manifesto. Br. J. Manag. 2020, 31, 447-449. [CrossRef]

199. Bajaj, S.; Garg, R.; Sethi, M. Total quality management: A critical literature review using Pareto analysis. Int. J. Prod. Perform. Manag. 2018, 67, 128-154. [CrossRef]

200. Karuppusami, G.; Gandhinathan, R. Pareto analysis of critical success factors of total quality management. TQM Mag. 2006, 18, 372-385. [CrossRef]

201. Aquilani, B.; Silvestri, C.; Ruggieri, A.; Gatti, C. A systematic literature review on total quality management critical success factors and the identification of new avenues of research. TQM J. 2017, 29, 184-213. [CrossRef]

202. Nicola, M.; Alsafi, Z.; Sohrabi, C.; Kerwan, A.; Al-Jabir, A.; Iosifidis, C.; Agha, M.; Agha, R. The socio-economic implications of the coronavirus pandemic (COVID-19): A review. Int. J. Surg. 2020, 78, 185-193. [CrossRef] [PubMed]

203. Sommer, L. Industrial revolution-Industry 4.0: Are German manufacturing SMEs the first victims of this revolution? J. Ind. Eng. Manag. 2015, 8, 1512-1532. [CrossRef]

204. Taiminen, H.M.; Karjaluoto, H. The usage of digital marketing channels in SMEs. J. Small Bus. Enterp. Dev. 2015, $22,633-651$. [CrossRef]

205. Hansmann, R.; Mieg, H.A.; Frischknecht, P. Principal sustainability components: Empirical analysis of synergies between the three pillars of sustainability. Int. J. Sustain. Dev. World Ecol. 2012, 19, 451-459. [CrossRef]

206. Knight, G.; Cavusgil, S.T.; Innovation, O.C. The Born-global Firm. J. Int. Bus. Stud. 2004, 35, 124-141. [CrossRef]

207. Piccarozzi, M.; Aquilani, B.; Gatti, C. Industry 4.0 in Management Studies: A Systematic Literature Review. Sustainability 2018, 10, 3821. [CrossRef]

208. Lam, T.; Cho, V.; Qu, H. A study of hotel employee behavioural intentions towards adoption of information technology. Int. J. Hosp. Manag. 2007, 26, 49-65. [CrossRef]

209. Kim, R.Y. The Impact of COVID-19 on Consumers: Preparing for Digital Sales. IEEE Eng. Manag. Rev. 2020, 48, 212-218. [CrossRef]

210. Hakovirta, M.; Denuwara, N. How COVID-19 Redefines the Concept of Sustainability. Sustainability 2020, 12, 3727. [CrossRef]

211. Elkington, J. Cannibals with Forks: The Triple Bottom Line of 21st Century Business; Capstone Publishing Ltd.: Oxford, UK, 1997.

212. Matt, C.; Hess, T.; Benlian, A. Digital Transformation Strategies. Bus. Inf. Syst. Eng. 2015, 57, 339-343. [CrossRef]

213. Sharp, L. Society 5.0: A brave new world. Impact 2020, 2020, 2-3. [CrossRef] 